\title{
Fluor-schorl, a new member of the tourmaline supergroup, and new data on schorl from the cotype localities
}

\author{
ANDREAS ERTL ${ }^{1,2, *}$, Uwe KOLITSCH ${ }^{1,2}$, M. DARBy DYAR ${ }^{3}$, HANS-PETER MEYER ${ }^{4}$, GEORGE R. ROSSMAN ${ }^{5}$, \\ DARRELl J. HENRY ${ }^{6}$, MARKUS PREM ${ }^{2}$, THOMAS LUDWIG ${ }^{4}$, LUTZ NASDALA ${ }^{2}$, CHRISTIAN L. LENGAUER ${ }^{2}$, \\ EKKEHART TILLMANNS ${ }^{2}$ and GERHARD NIEDERMAYR ${ }^{1}$
}

\author{
${ }^{1}$ Mineralogisch-Petrographische Abt., Naturhistorisches Museum, Burgring 7, 1010 Vienna, Austria \\ *Corresponding author, e-mail: andreas.ertl@a1.net \\ ${ }^{2}$ Institut für Mineralogie und Kristallographie, Geozentrum, Universität Wien, Althanstrasse 14, 1090 Vienna, \\ Austria \\ ${ }^{3}$ Department of Geography and Geology, Mount Holyoke College, South Hadley, Massachusetts 01075, USA \\ ${ }^{4}$ Institut für Geowissenschaften, Universität Heidelberg, Im Neuenheimer Feld 236, 69120 Heidelberg, Germany \\ ${ }^{5}$ Division of Geological and Planetary Sciences, California Institute of Technology, Pasadena, \\ California 91125-2500, USA \\ ${ }^{6}$ Department of Geology and Geophysics, Louisiana State University, Baton Rouge, Louisiana 70803, USA
}

\begin{abstract}
Fluor-schorl, $\mathrm{NaFe}_{3}^{2+}{ }_{3} \mathrm{Al}_{6} \mathrm{Si}_{6} \mathrm{O}_{18}\left(\mathrm{BO}_{3}\right)_{3}(\mathrm{OH})_{3} \mathrm{~F}$, is a new mineral species of the tourmaline supergroup from alluvial tin deposits near Steinberg, Zschorlau, Erzgebirge (Saxonian Ore Mountains), Saxony, Germany, and from pegmatites near Grasstein (area from Mittewald to Sachsenklemme), Trentino, South Tyrol, Italy. Fluor-schorl was formed as a pneumatolytic phase and in high-temperature hydrothermal veins in granitic pegmatites. Crystals are black (pale brownish to pale greyish-bluish, if $<0.3 \mathrm{~mm}$ in diameter) with a bluish-white streak. Fluor-schorl is brittle and has a Mohs hardness of 7; it is non-fluorescent, has no observable parting and a poor/indistinct cleavage parallel to $\{0001\}$. It has a calculated density of $\sim 3.23 \mathrm{~g} / \mathrm{cm}^{3}$. In plane-polarized light, it is pleochroic, $O=$ brown to grey-brown (Zschorlau), blue (Grasstein), $E=$ pale grey-brown (Zschorlau), cream (Grasstein). Fluorschorl is uniaxial negative, $\omega=1.660(2)-1.661(2), \varepsilon=1.636(2)-1.637(2)$. The mineral is rhombohedral, space group $R 3 m, a=$ 16.005(2), $c=7.176(1) \AA, V=1591.9(4) \AA^{3}$ (Zschorlau), $a=15.995(1), c=7.166(1) \AA, V=1587.7(9) \AA^{3}$ (Grasstein), $Z=3$. The eight strongest observed X-ray diffraction lines in the powder pattern $[d$ in $\AA(I) h k l]$ are: $2.584(100)(051), 3.469(99)(012)$, $2.959(83)(122), 2.044(80)(152), 4.234(40)(211), 4.005(39)(220), 6.382(37)(101), 1.454(36)(514)$ (Grasstein). Analyses by a combination of electron microprobe, secondary-ion mass spectrometry (SIMS), Mössbauer spectroscopic data and crystal-structure refinement result in the structural formulae ${ }^{X}\left(\mathrm{Na}_{0.82} \mathrm{~K}_{0.01} \mathrm{Ca}_{0.01} \square_{0.16}\right){ }^{Y}\left(\mathrm{Fe}^{2+}{ }_{2.30} \mathrm{Al}_{0.38} \mathrm{Mg}_{0.23} \mathrm{Li}_{0.03} \mathrm{Mn}^{2+}{ }_{0.02} \mathrm{Zn}_{0.01} \square_{0.03}\right)_{\Sigma 3.00}$

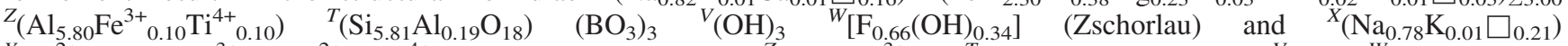
${ }^{Y}\left(\mathrm{Fe}^{2+}{ }_{1.89} \mathrm{Al}_{0.58} \mathrm{Fe}^{3+}{ }_{0.13} \mathrm{Mn}^{2+}{ }_{0.13} \mathrm{Ti}^{4+}{ }_{0.02} \mathrm{Mg}_{0.02} \mathrm{Zn}_{0.02} \square_{0.21}\right)_{\Sigma 3.00}{ }^{\mathrm{Z}}\left(\mathrm{Al}_{5.74} \mathrm{Fe}^{3+}{ }_{0.26}{ }^{T}\left(\mathrm{Si}_{5.90} \mathrm{Al}_{0.10} \mathrm{O}_{18}\right)\left(\mathrm{BO}_{3}\right)_{3}{ }^{V}(\mathrm{OH})_{3}{ }^{W}\left[\mathrm{~F}_{0.76}(\mathrm{OH})_{0.24}\right]\right.$ (Grasstein). Several additional, newly confirmed occurrences of fluor-schorl are reported. Fluor-schorl, ideally $\mathrm{NaFe}_{3}^{2+}{ }_{3} \mathrm{Al}_{6} \mathrm{Si}_{6} \mathrm{O}_{18}\left(\mathrm{BO}_{3}\right)_{3}(\mathrm{OH})_{3} \mathrm{~F}$, is related to end-member schorl by the substution $\mathrm{F} \rightarrow(\mathrm{OH})$. The chemical compositions and refined crystal structures of several schorl samples from cotype localities for schorl (alluvial tin deposits and tin mines in the Erzgebirge, including Zschorlau) are also reported. The unit-cell parameters of schorl from these localities are slightly variable, $a=$ 15.98-15.99, $c=7.15-7.16 \AA$, corresponding to structural formulae ranging from $\sim^{X}\left(\mathrm{Na}_{0.5} \square 0.5\right){ }^{Y}\left(\mathrm{Fe}^{2+}{ }_{1.8} \mathrm{Al}_{0.9} \mathrm{Mg}_{0.2} \square_{0.1}\right)$ ${ }^{Z}\left(\mathrm{Al}_{5.8} \mathrm{Fe}^{3+}{ }_{0.1} \mathrm{Ti}^{4+}{ }_{0.1}\right){ }^{T}\left(\mathrm{Si}_{5.7} \mathrm{Al}_{0.3} \mathrm{O}_{18}\right)\left(\mathrm{BO}_{3}\right)_{3} V_{(\mathrm{OH})_{3}}{ }^{W}\left[(\mathrm{OH})_{0.9} \mathrm{~F}_{0.1}\right]$ to $\sim^{X}\left(\mathrm{Na}_{0.7} \square_{0.3}\right)^{Y}\left(\mathrm{Fe}^{2+}{ }_{2.1} \mathrm{Al}_{0.7} \mathrm{Mg}_{0.1} \square_{0.1}\right){ }^{Z}\left(\mathrm{Al}_{5.9} \mathrm{Fe}^{3+}{ }_{0.1}\right)$ ${ }^{T}\left(\mathrm{Si}_{5.8} \mathrm{Al}_{0.2} \mathrm{O}_{18}\right)\left(\mathrm{BO}_{3}\right)_{3}{ }^{V}(\mathrm{OH})_{3}{ }^{W}\left[(\mathrm{OH})_{0.6} \mathrm{~F}_{0.4}\right]$. The investigated tourmalines from the Erzgebirge show that there exists a complete fluor-schorl-schorl solid-solution series. For all studied tourmaline samples, a distinct inverse correlation was observed between the $X-\mathrm{O} 2$ distance (which reflects the mean ionic radius of the $X$-site occupants) and the $\mathrm{F}$ content $\left(r^{2}=0.92\right)$. A strong positive correlation was found to exist between the $\mathrm{F}$ content and the $\langle Y-\mathrm{O}\rangle$ distance $\left(r^{2}=0.93\right)$. This correlation indicates that $\mathrm{Fe}^{2+}$-rich tourmalines from the investigated localities clearly tend to have a F-rich or F-dominant composition. A further strong positive correlation $\left(r^{2}=0.82\right)$ exists between the refined $\mathrm{F}$ content and the $Y-W(\mathrm{~F}, \mathrm{OH})$ distance, and the latter may be used to quickly estimate the $\mathrm{F}$ content.
\end{abstract}

Key-words: fluor-schorl; schorl; new mineral; Erzgebirge; type locality; Zschorlau; Grasstein; crystal structure; chemical composition; tourmaline. 


\section{Introduction and previous work}

The general chemical formula of the tourmaline-supergroup minerals can be written as $X Y_{3} Z_{6}\left[T_{6} \mathrm{O}_{18}\right]\left(\mathrm{BO}_{3}\right)_{3}$ $V_{3} W$, as proposed by Henry et al. (2010). These authors and Hawthorne $(1996,2002)$ suggest occupancies by the following most common cations:

$$
\begin{aligned}
& X=\mathrm{Na}, \mathrm{K}, \mathrm{Ca}, \square \text { (vacancy) } \\
& Y=\mathrm{Mg}, \mathrm{Fe}^{2+}, \mathrm{Mn}^{2+}, \mathrm{Al}, \mathrm{Li}, \mathrm{Fe}^{3+}, \mathrm{Cr}^{3+}, \mathrm{V}^{3+} \\
& Z=\mathrm{Al}, \mathrm{Mg}, \mathrm{Fe}^{3+}, \mathrm{V}^{3+}, \mathrm{Cr}^{3+} \\
& T=\mathrm{Si}, \mathrm{Al}, \mathrm{B} \\
& V=\text { OH. O. } \\
& W=\text { OH. F. O. }
\end{aligned}
$$

Crystal-chemical relationships in the tourmaline supergroup and crystal chemistry of the schorl-dravite series have been investigated by Bosi \& Lucchesi (2004, 2007). Tourmalines with the ideal formula $\mathrm{NaFe}^{2+}{ }_{3} \mathrm{Al}_{6} \mathrm{Si}_{6} \mathrm{O}_{18}$ $\left(\mathrm{BO}_{3}\right)_{3}(\mathrm{OH})_{3} \mathrm{~F}$ have already been described by Novák et al. (1998) and Burianek \& Novák (2004) from Moravia, Czech Republic, by Ertl et al. (2006) from South Tyrol, Italy, by Kolitsch et al. (2011, 2013) from Nordland, Norway, by Shirose \& Uehara (2013) from the Kyushu Region, Japan, by Dixon et al. (2014) from British Columbia, Canada, and by Boudreaux et al. (2014) from the miarolitic NYF Erongo Granite in the Erongo Complex of Namibia. In 2011 both the name and the mineral fluorschorl (2010-067) have been approved by the IMA Commission on New Minerals, Nomenclature and Classification (CNMNC) as a new member of the tourmaline supergroup (Ertl et al., 2011).

In a survey on the incorporation of fluorine in tourmaline, Henry \& Dutrow (2011) pointed out that tourmaline in fluorite-bearing rocks can usually be assigned to fluorschorl. They further stated that tourmalines associated with fluorite in these petrologic environments generally outline the boundary of the F range defined by their cumulative data set, implying that crystallochemical constraints limit these tourmaline compositions as well. Henry \& Dutrow (2011) conclude that these fluor-species are relatively common in the alkali-group of tourmaline.

In this work we investigate black tourmalines from the area near Grasstein (South Tyrol, Italy; Ertl et al., 2006) and from different localities in the Erzgebirge (former tin mines in Saxony, Germany, and Krušné Hory Mts., Bohemia, Czech Republic). Additional data will be briefly given below for fluor-schorl from additional localities newly confirmed by us.

The early history of the mineral schorl shows that the name "Schorl" was in use prior to the year $1400 \mathrm{AD}$ because a village known today as Zschorlau (in Saxony, Germany) was then named "Schorl" (or minor variants of this name). This village had a nearby tin mine where, in addition to cassiterite, a lot of black tourmaline was found
(Ertl, 2006). Around 200 years later followed the first relatively detailed description of schorl and its occurrence (various alluvial tin deposits and tin mines in the Erzgebirge), which was published by Johannes Mathesius (Mathesij, 1562). Mathesius described schorl originally as "schürl", with the properties black, a lighter weight than cassiterite ("zynstein") and that it breaks easily. In that publication schorl should not be confused with "wolframite", which he describes as heavier than cassiterite, while pointing out that, when it comes together with cassiterite in the furnace, it ("wolframite") produces much slag and makes the tin hard and white spotted (Mathesij, 1562; Ertl, 2006).

We tried to obtain black tourmaline samples from these localities, which were originally described by Mathesius as: "Erbarsdorff" (later called Ebersdorf; today named Ehrenfriedersdorf, Saxony, Germany; Schiffner, 1839), "Geyer" (today also Geyer, Saxony), "Altenberg" (today also Altenberg, Saxony), "Schlackawalde" (later called Schlackenwald or Schlaggenwald; today named Horní Slávkov in Bohemia, Czech Republic), "Neideck" (later called Neudek; today named Nejdek, Bohemia), "Plat" (later called Platten or Bergstadt Platten; today named Horní Blatná, Bohemia), "Perlinger" (later called Perninger, Berninger or Bärringen; today named Pernink, Bohemia), near "Gotsgabe" (later called Gottesgab; today named Boží Dar, Bohemia), "am Schwartzwasser hinter dem Spitzberg" (later called river Schwarzwasser behind Spitzberg mountain; today river Černá near Boží Dar), "Muckenberg" (later Mückenberg near Halbmeil, belongs today to Boží Dar), "hengst" (also "am großen Hengst", later called Seifen, then Ryžovna, which belongs since 1955 also to Boží Dar), and "umb den Schneberg" (area around village Schneeberg; the small former village Schorlau, today named Zschorlau, is also located close to Schneeberg) (see also Ertl, 2006). We only successfully obtained samples from the Schneeberg District (sample designation SCHN1, Schneeberg; LIN, from a quarry (mined for cassiterite at Sandberg) near Lindenau, since 1999 a district of the village Schneeberg; ZSCH, several samples from alluvial tin deposits near Am Steinberg close to village Zschorlau), from Ehrenfriedersdorf (SAU2, Sauberg Mine) and from Nejdek (NEUDEK). In addition, we characterize black tourmaline from Johanngeorgenstadt, Erzgebirge, Saxony (JOH).

\section{Type material}

Parts of the cotype material of fluor-schorl are deposited in the collections of the Naturhistorisches Museum, Vienna, Austria (N 8165 from Zschorlau; N 8166 from Grasstein). Parts of the cotype material of fluor-schorl from Grasstein have also been catalogued by the "Museum of Nature South Tyrol", Bozen/Bolzano, Italy (catalogue no. MIN 9777). Parts of the cotype material of fluor-schorl from Zschorlau have also been deposited in the collections (Mineralogische Sammlung, Geowissenschaftliche Sammlungen) of the TU Bergakademie Freiberg, 
Freiberg, Saxony, Germany, with the number MiSa 83180. Additional cotype material of fluor-schorl and schorl (an exhibition specimen with both tourmalines from Zschorlau) was deposited with the number MiSa 83181. Additional cotype material of schorl is deposited in the collections of the Naturhistorisches Museum, Vienna, Austria (from Nejdek, N 9974).

\section{Petrological settings of studied samples}

\subsection{Erzgebirge/Krušné Hory Mountains}

Tourmaline samples were either obtained or self-collected from several localities throughout the Erzgebirge/Krušné Hory Mountains including locations near Schneeberg (including Zschorlau, Germany), Johanngeorgenstadt (Germany), Ehrenfriedersdorf (Germany) and Nejdek (Czech Republic). All of the fluor-schorl and schorl samples are from pegmatitic bodies related to the latecollisional granites $(\sim 325-318 \mathrm{Ma})$ that were emplaced at shallow crustal levels $(\sim 0.2 \mathrm{GPa})$ in the Variscan metamorphic basement (Förster et al., 1999; Romer et al., 2007). The granites can be strongly peraluminous S-type rocks with the highest degree of differentiation reached in the Li-mica granites which contain strongly elevated concentrations of $\mathrm{P}, \mathrm{F}, \mathrm{Li}, \mathrm{Rb}, \mathrm{Cs}, \mathrm{Ta}, \mathrm{Sn}, \mathrm{W}$ and $\mathrm{U}$ (Förster et al., 1999). All of the fluor-schorl that is considered pneumatolytic occurs in areas with tin mineralization. The cotype locality of fluor-schorl is the area of alluvial tin deposits near Am Steinberg, Zschorlau, Erzgebirge, Saxony, Germany. Here fluor-schorl is closely associated with quartz, biotite, albite, orthoclase, schorl (occurs also in the Zschorlau "Bergsegen" wolframite mine as dark green to almost black aggregates, consisting of fibrous crystals embedded in quartz; Tschiebel, 2000a and b), apatite, beryl, cassiterite and "wolframite" (see also Ertl, 2006; Tschiedel, 2006). Fluor-schorl occurs typically as striated prismatic crystals, up to $\sim 1 \times 10 \mathrm{~mm}$, that are often radially arranged and found in small quartz veins intergrown with quartz and feldspar, and rarely grown on quartz crystals.

\subsection{Grasstein, Trentino - South Tyrol, Italy}

The cotype locality of fluor-schorl is the area around Grasstein (from Mittewald to Sachsenklemme), west of the village of Mittewald, Trentino, South Tyrol, Italy. Fluor-schorl occurs there in pegmatites, which are associated with the shallow-level, $\sim 280$ Ma Brixener granite (Del Moro \& Visonà, 1982; Rottura et al., 1997). Small veins in this pegmatite contain quartz crystals (up to $\sim 1 \mathrm{~cm}$ in length) with tiny prismatic tourmaline crystals grown on their top. These tourmaline crystals show a pale brownish to pale greyish-bluish colour and have a maximum size of $\sim 1 \mathrm{~mm}$. Similar F-rich, prismatic tourmalines are locally intergrown with quartz, have a brown-black colour, show strong dichroism, and reach a size of up to $\sim 8 \mathrm{~mm}$. There appear to be two different phases of development in the pegmatitic body: a pneumatolytic phase and a hydrothermal phase (Kreuzeder, 1949). The pneumatolytic phase includes fluor-schorl as well as fluorite, axinite, epidote, pyrrhotite, molybdenite, galena, chalcopyrite and pyrite. Fluor-schorl occurs as prismatic crystals, up to $\sim 5 \times$ $10 \mathrm{~mm}$, intergrown with quartz and rarely grown on quartz crystals. The hydrothermal phase includes zoisite, garnet, prehnite, albite, muscovite, talc, chlorite, chabazite, stilbite, laumontite, apophyllite and calcite.

\section{Additional fluor-schorl occurrences}

Among more than 50 different studied samples of dark tourmaline from world-wide occurrences, the ones briefly described below were all confirmed as fluor-schorl by single-crystal structure refinements and chemical analyses (scanning electron microscope - energy dispersive X-ray spectroscopy).

- Dark brown, subparallel prisms in quartz from the Roter Berg mining district, Schneeberg, Saxony, Germany (collection Joachim Gröbner, Clausthal, Germany).

- A black prism, associated with pale greenish hexahedra of fluorite and yellowish to ivory-coloured K-feldspar crystals, from a granite pegmatite in the Epprechtstein quarry, Kirchenlamitz, Fichtelgebirge, Franken, Bavaria, Germany (Naturhistorisches Museum, Vienna, Austria; catalogue no. J 7975).

- A black prism from a granite pegmatite at Nedvědice, Vysočina Region, Moravia (Mähren; Maehren), Czech Republic, obtained from Jan Cempírek; fragments from both core and rim of the crystal have similar compositions. The analytical result confirms previous data for tourmaline from this locality (Novák et al., 1998).

- Several samples with black prisms, associated with pale greenish, rounded (corroded) octahedral fluorite crystals, minor (hydroxyl-?)herderite, and schorl from the famous granite pegmatites (see also Niedermayr \& Schnaitmann, 2010; Niedermayr et al., 2012) in the Erongo Region (in part from farm Davib West), Namibia (gifts from Lars Epple, Gerlingen, Germany, and Herbert Kaiser, Maria Enzersdorf, Austria). The F-dominance in these samples is consistent with data on rock-forming tourmaline in the Erongo granite (Trumbull et al., 2008).

- A thick black prism, associated with reddish K-feldspar, from the Mile 72 pegmatite, Swakopmund, Erongo Region, Namibia (self-collected by UK).

- Black-brown, crude prisms, associated quartz and feldspar, from a pegmatite patch in the Lake Boga granite quarry, Australia (self-collected by UK).

The samples closest to the fluor-schorl end-member composition were those in direct assocation with (apparently contemporaneously crystallised) fluorite (Epprechtstein and Erongo localities, with $\sim 0.8$ apfu F). This observation is not unexpected and confirms the conclusions of Henry \& Dutrow (2011). 


\section{Experimental details}

\subsection{Crystal-structure refinement}

The tourmaline crystal structures were determined at ambient temperature with either a Bruker Apex chargecoupled device (CCD) or a Nonius KappaCCD singlecrystal diffractometer using graphite-monochromated Mo $K \alpha$ radiation. Crystal data, data collection information and refinement details are given in Table 1. Highly redundant data were collected for an approximate sphere of reciprocal space, and were integrated and corrected for Lorentz and polarization factors, and absorption correction, using the Bruker program SAINTPLus for BLS1 (Bruker AXS Inc., 2001) or the Nonius programs COLLECT and DENZO-SMN (Nonius, 2007) and multi-scan absorption correction (Otwinowski et al., 2003) for the remaining samples. The structures were refined with SHELXL-97 (Sheldrick, 2008) using scattering factors for neutral atoms and the structure model from Fortier \& Donnay (1975) as a starting model. During all refinements, the $X$ site was modelled with Na scattering factors and unconstrained occupancy, and the $Y$ site and $Z$ site were similarly modelled using $\mathrm{Al}$ and $\mathrm{Fe}$ scattering factors. The $T$ site was modelled using Si scattering factors, but with fixed occupancy of $\mathrm{Si}_{1.00}$, because refinement with unconstrained occupancy showed this site to be essentially fully occupied by $\mathrm{Si}$ within error limits. The B site was modelled with fixed occupancy of $\mathrm{B}_{1.00}$. The $\mathrm{H}$ site was freely refined. The F:O ratio on the $W$ site was freely refined and found to be in generally excellent agreement with the electronprobe microanalysis (EPMA) data (see below); it was observed that a check of the measured intensity of the very weak 120 reflection in the datasets was necessary - if this reflection was blocked or partially obscured by the beam stop (easily visible from the resulting anomalously large discrepancy between the measured and calculated intensity), the refined $\mathrm{F}: \mathrm{O}$ ratio was less reliable due to an

Table 1. Crystal data, data collection information and refinement details for fluor-schorl and schorl.

\begin{tabular}{|c|c|c|c|c|c|}
\hline Sample & $\operatorname{GRAS} 1^{1, *}$ & $\mathrm{ZSCH}^{1, *}$ & ZSCH4B* & ZSCH6** & $\mathrm{ZSCH} 2 * *$ \\
\hline$a(\AA) c(\AA)$ & $15.997(2) 7.179(1)$ & $16.005(2) 7.176(1)$ & $15.995(2) 7.157(1)$ & $15.991(2) 7.162(1)$ & $15.982(2) 7.159(1)$ \\
\hline$V\left(\AA^{3}\right)$ & $1591.0(4)$ & $1591.9(4)$ & $1585.7(4)$ & $1586.1(4)$ & $1583.6(4)$ \\
\hline Collection mode, $2 \theta_{\max }\left(^{\circ}\right)$ & full sphere, 69.92 & full sphere, 75.47 & full sphere, 75.43 & full sphere, 75.55 & full sphere, 75.49 \\
\hline$h, k, l$ ranges & $\begin{array}{l}-25 / 25,-21 / 21 \\
-11 / 11\end{array}$ & $\begin{array}{l}-27 / 27,-23 / 23 \\
-12 / 12\end{array}$ & $\begin{array}{l}-27 / 27,-23 / 23 \\
\quad-12 / 12\end{array}$ & $\begin{array}{l}-27 / 27,-23 / 23 \\
\quad-12 / 12\end{array}$ & $\begin{array}{l}-27 / 27,-23 / 23 \\
\quad-12 / 12\end{array}$ \\
\hline Total reflections measured & 3116 & 3772 & 3764 & 3770 & 3761 \\
\hline Unique reflections & $1695\left(R_{\text {int }} 0.97 \%\right)$ & $2039\left(R_{\text {int }} 1.00 \%\right)$ & $2033\left(R_{\text {int }} 1.09 \%\right)$ & $2038\left(R_{\text {int }} 1.53 \%\right)$ & $2034\left(R_{\text {int }} 1.15 \%\right)$ \\
\hline$R 1(F), \mathrm{w} R 2_{\mathrm{all}}\left(F^{2}\right)$ & $1.60 \%, 4.10 \%$ & $1.77 \%, 4.49 \%$ & $1.86 \%, 4.67 \%$ & $2.20 \%, 5.24 \%$ & $1.97 \%, 4.71 \%$ \\
\hline Flack $x$ parameter & $-0.002(11)$ & $-0.007(11)$ & $-0.001(12)$ & $-0.014(14)$ & $-0.005(13)$ \\
\hline $\begin{array}{l}\text { 'Observed' refls. } \\
\qquad\left[F_{\mathrm{o}}>4 \sigma\left(F_{\mathrm{o}}\right)\right]\end{array}$ & 1682 & 2021 & 2004 & 1986 & 2005 \\
\hline Extinct. coefficient & $0.00129(13)$ & $0.00298(17)$ & $0.00090(13)$ & $0.00102(14)$ & $0.00332(17)$ \\
\hline No. of refined parameters & 96 & 96 & 96 & 96 & 96 \\
\hline GooF & 1.129 & 1.144 & 1.117 & 1.151 & 1.214 \\
\hline$(\Delta / \sigma)_{\max }$ & 0.001 & 0.001 & 0.001 & 0.000 & 0.000 \\
\hline$\Delta \sigma_{\min }, \Delta \sigma_{\max }\left(\mathrm{e} / \AA^{3}\right)$ & $-0.71,0.81$ & $-0.88,0.99$ & $-0.85,1.02$ & $-0.75,0.92$ & $-0.72,0.82$ \\
\hline
\end{tabular}

\begin{tabular}{lllll} 
Sample & JOH $^{*}$ & LIN* & SCHN1** & NEUDEK** \\
\hline$a(\AA) c(\AA)$ & $15.993(2) 7.168(1)$ & $15.987(2) 7.165(1)$ & $15.981(2) 7.158(1)$ & $15.978(2) 7.146(1)$ \\
$V\left(\AA^{3}\right)$ & $1587.8(4)$ & $1585.9(4)$ & $1583.2(4)$ & $1579.9(4)$ \\
Collection mode, $2 \theta_{\max }\left({ }^{\circ}\right)$ & full sphere, 75.50 & full sphere, 75.54 & full sphere, 75.50 & full sphere, 75.48 \\
$h, k, l$ ranges & $-27 / 27,-23 / 23,-12 / 12$ & $-27 / 27,-23 / 23,-12 / 12$ & $-27 / 27,-23 / 23,-12 / 12$ & $-27 / 27,-23 / 23,-12 / 12$ \\
Total reflections measured & 3774 & 3770 & 3765 & 3762 \\
Unique reflections & $2039\left(R_{\text {int }} 1.12 \%\right)$ & $2037\left(R_{\text {int }} 1.14 \%\right)$ & $2034\left(R_{\text {int }} 1.05 \%\right)$ & $2033\left(R_{\text {int }} 1.51 \%\right)$ \\
$R 1(F)$, w $R 2_{\text {all }}\left(F^{2}\right)$ & $1.79 \%, 4.62 \%$ & $1.92 \%, 4.91 \%$ & $1.64 \%, 4.29 \%$ & $2.20 \%, 5.31 \%$ \\
Flack $x$ parameter & $0.004(11)$ & $0.000(12)$ & $0.019(11)$ & $-0.007(14)$ \\
'Observed' refls. & 2019 & 2005 & 2016 & 1977 \\
$\quad\left[F_{\mathrm{o}}>4 \sigma\left(F_{\mathrm{o}}\right)\right]$ & & & $0.00135(13)$ & $0.00041(14)$ \\
Extinct. coefficient & $0.00220(16)$ & $0.00091(14)$ & 96 & 96 \\
No. of refined parameters & 96 & 96 & 1.128 & 0.000 \\
GooF & 1.126 & 1.121 & $-0.77,0.87$ & 0.000 \\
$(\Delta / \sigma)_{\text {max }}$ & 0.000 & 0.000 & $-0.93,1.18$ & $-0.60,0.99$
\end{tabular}

Notes: Diffractometer: Nonius KappaCCD system; space group $R 3 m$; refinement on $F^{2}$. Unit-cell parameters have been refined from approximately 5500 reflections in each case. ${ }^{1}$ Cotype material of fluor-schorl (GRAS1 from Grasstein, ZSCH8 from Zschorlau). Singlecrystal data from Ertl et al. (2006). *Fluor-schorl. ** Schorl from different cotype localities for schorl in the Erzgebirge/Krušné Hory Mountains (Novák et al., 2009; Henry et al., 2010). See text (Introduction) for sample localities. 
increased standard uncertainty. From our extensive experience with high-resolution, single-crystal tourmaline datasets, the refined $\mathrm{F}$ content of a given tourmaline is accurate to within 0.1-0.2 atoms per formula unit (apfu). The final refinement was performed with anisotropic thermal parameters for all non-hydrogen atoms. Table 2 lists the atom parameters and Table 3 presents selected interatomic distances.

\subsection{Powder X-ray diffraction}

An automated X-ray powder diffractometer (PHILIPS X'Pert - PW3020) was used for recording the X-ray powder data for fluor-schorl. We used $\mathrm{Cu} K \alpha 1$ radiation $(\lambda=$ $1.54056 \AA$ ), at $40 \mathrm{kV}$ and $40 \mathrm{~mA}$. Silicon (SRM640c) was employed as internal standard for both the Zschorlau and Grasstein samples. Quartz was used for calibration (by

Table 2. Positional parameters and their estimated standard deviations for fluor-schorl and schorl (localities in South Tyrol and Erzgebirge/ Krušné Hory Mountains).

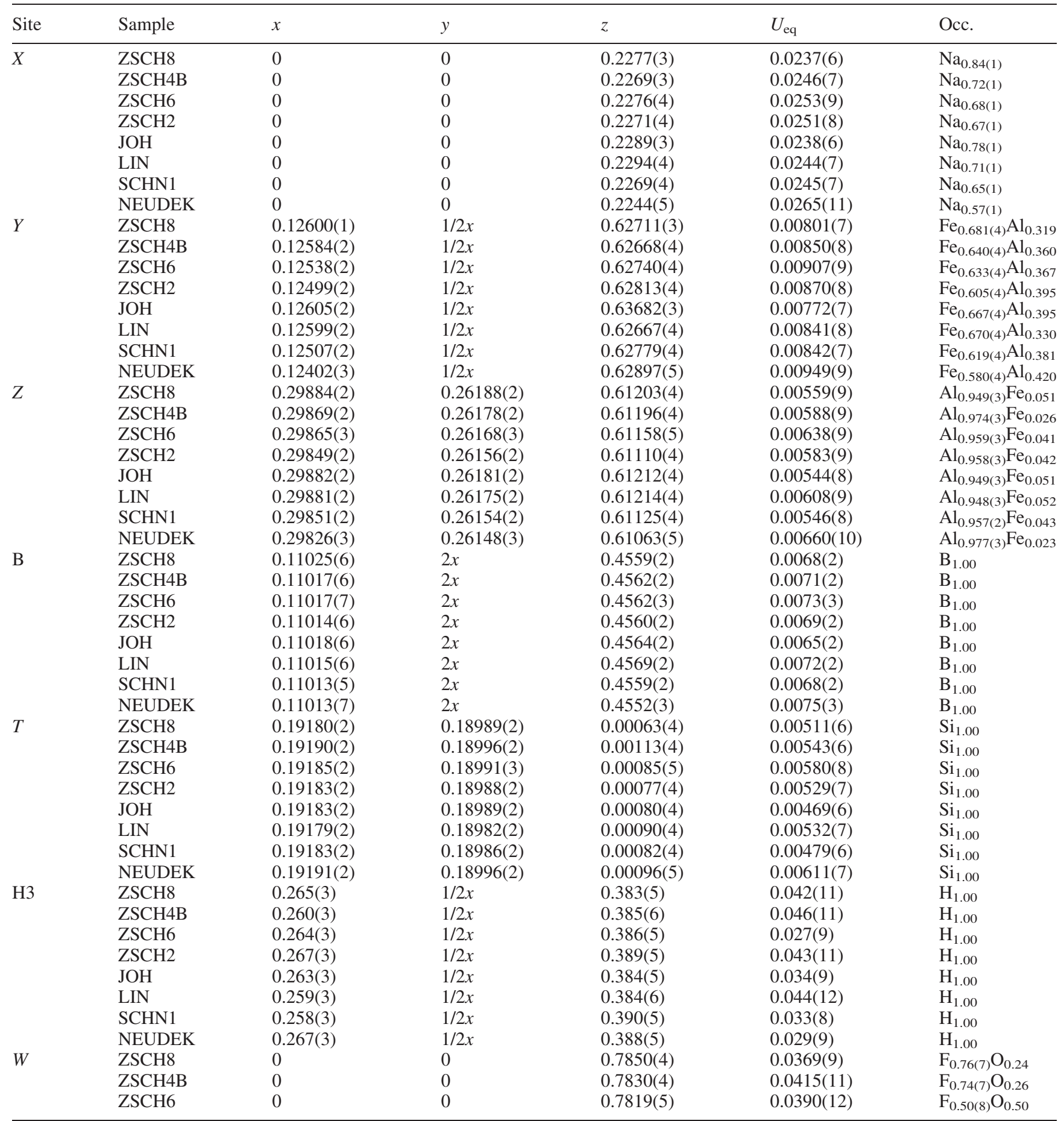


Table 2. Continued

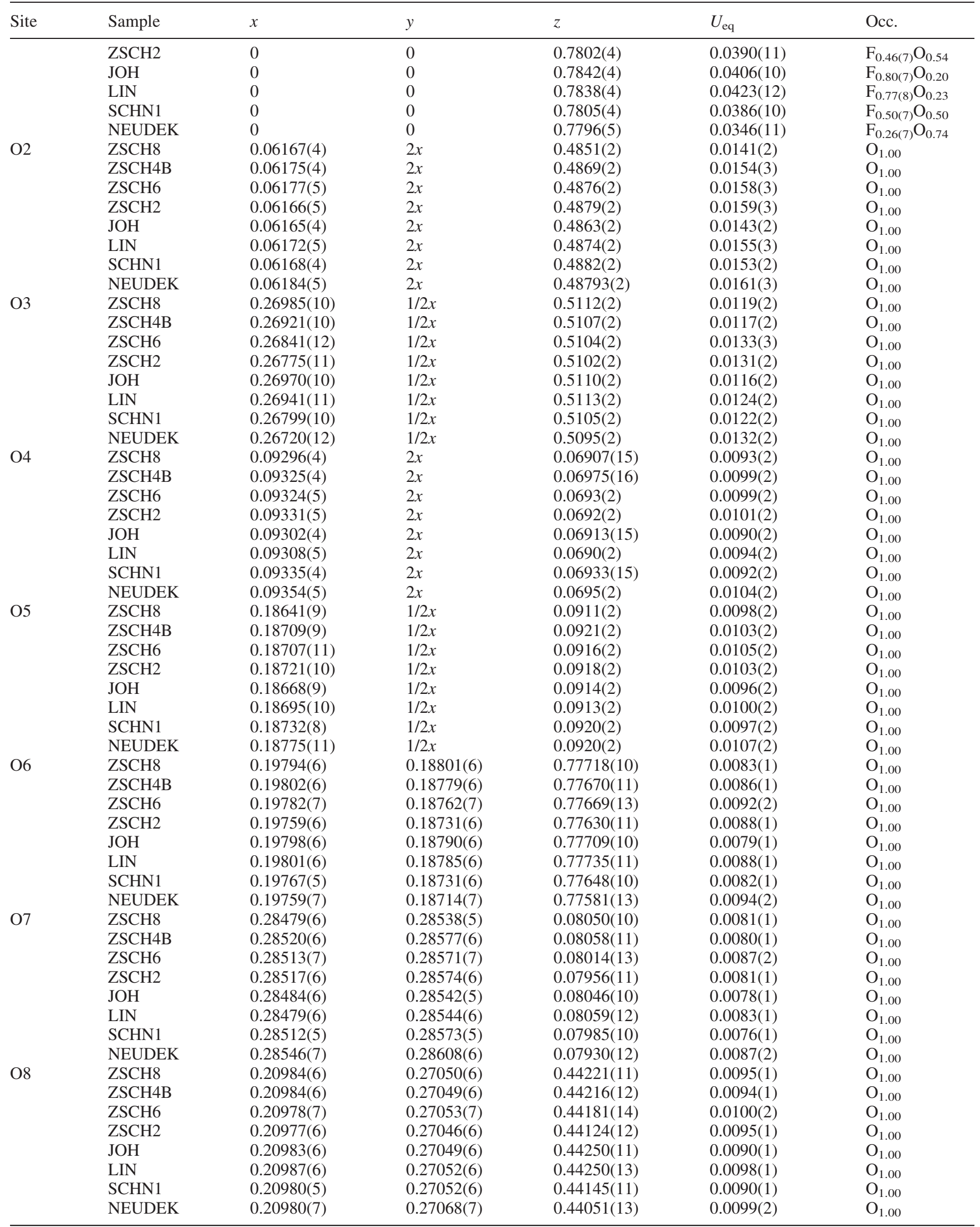

Note: For definition of $U_{e q}$ see Fischer \& Tillmanns (1988). 
Table 3. Selected interatomic distances ( $)$ in fluor-schorl and schorl (localities in South Tyrol and Erzgebirge/Krušné Hory Mountains).

\begin{tabular}{|c|c|c|c|c|c|c|c|c|c|}
\hline$X_{-}$ & GRAS1 & ZSCH8 & ZSCH4B & ZSCH6 & ZSCH2 & $\mathrm{JOH}$ & LIN & SCHN1 & NEUDEK \\
\hline O5 (x3) & $2.7658(15)$ & $2.7635(14)$ & $2.7653(15)$ & $2.7678(18)$ & $2.7663(16)$ & $2.7670(15)$ & $2.7709(16)$ & $2.7666(15)$ & $2.765(2)$ \\
\hline Mean & 2.699 & 2.699 & 2.704 & 2.704 & 2.705 & 2.700 & 2.704 & 2.706 & 2.709 \\
\hline \multicolumn{10}{|l|}{$Y-$} \\
\hline $\mathrm{O} 2(\mathrm{x} 2)$ & $2.0019(9)$ & $2.0064(2)$ & $1.9959(9)$ & $1.9934(10)$ & $1.9904(9)$ & $1.9995(8)$ & $1.9947(9)$ & $1.9887(8)$ & $1.9882(10)$ \\
\hline $\mathrm{O} 3$ & $2.1512(15)$ & $2.1605(14)$ & $2.1526(14)$ & $2.1508(17)$ & $2.1485(15)$ & $2.1557(14)$ & $2.1508(15)$ & $2.1490(13)$ & $2.1574(16)$ \\
\hline Mean & 2.056 & 2.058 & 2.050 & 2.046 & 2.040 & 2.053 & 2.051 & 2.040 & 2.037 \\
\hline \multicolumn{10}{|l|}{$Z-$} \\
\hline O6 & $1.8716(9)$ & $1.8710(9)$ & $1.8649(9)$ & $1.8685(10)$ & $1.8691(9)$ & $1.8682(8)$ & $1.8682(9)$ & $1.8686(8)$ & $1.8657(10)$ \\
\hline O7 & $1.8855(9)$ & $1.8852(8)$ & $1.8799(8)$ & $1.8819(10)$ & $1.8828(9)$ & $1.8842(8)$ & $1.8827(9)$ & $1.8816(8)$ & $1.8789(10)$ \\
\hline O8 & $1.8885(9)$ & $1.8878(8)$ & $1.8866(9)$ & $1.8871(10)$ & $1.8877(9)$ & $1.8871(8)$ & $1.8856(9)$ & $1.8868(8)$ & $1.8856(10)$ \\
\hline \multicolumn{10}{|l|}{$T-$} \\
\hline O6 & $1.6066(9)$ & $1.6077(8)$ & $1.6106(9)$ & $1.6098(10)$ & $1.6113(9)$ & $1.6078(8)$ & $1.6061(9)$ & $1.6102(8)$ & $1.6134(10)$ \\
\hline $\mathrm{O} 7$ & $1.6131(9)$ & $1.6139(8)$ & $1.6162(8)$ & $1.6153(10)$ & $1.6140(9)$ & $1.6126(8)$ & $1.6126(9)$ & $1.6143(8)$ & $1.6157(9)$ \\
\hline $\mathrm{O} 4$ & $1.6257(5)$ & $1.6269(5)$ & $1.6269(5)$ & $1.6258(6)$ & $1.6248(5)$ & $1.6260(5)$ & $1.6245(5)$ & $1.6250(5)$ & $1.6248(6)$ \\
\hline O5 & $1.6390(6)$ & $1.6401(6)$ & $1.6400(6)$ & $1.6388(7)$ & $1.6382(6)$ & $1.6388(5)$ & $1.6368(6)$ & $1.6381(5)$ & $1.6380(6)$ \\
\hline Mean & 1.621 & 1.622 & 1.623 & 1.622 & 1.622 & 1.621 & 1.620 & 1.622 & 1.623 \\
\hline \multicolumn{10}{|l|}{$\mathrm{B}-$} \\
\hline $\mathrm{O} 2$ & $1.360(2)$ & $1.363(2)$ & $1.360(2)$ & $1.359(2)$ & $1.361(2)$ & $1.361(2)$ & $1.359(2)$ & $1.3610(19)$ & $1.357(2)$ \\
\hline $\mathrm{O} 8$ (x2) & $1.3841(12)$ & $1.3839(11)$ & $1.3842(12)$ & $1.3833(14)$ & $1.3831(13)$ & $1.3838(12)$ & $1.3845(13)$ & $1.3832(11)$ & $1.3832(14)$ \\
\hline Mean & 1.376 & 1.377 & 1.376 & 1.375 & 1.376 & 1.376 & 1.376 & 1.376 & 1.374 \\
\hline
\end{tabular}

linear regression of the deviations) with the help of the program POWCALIB Version Beta 0.977 (1990). Indexing was based on calculated intensities obtained from the fluor-schorl structure refinements (this work, ZSCH8; Ertl et al., 2006).

\subsection{Chemical analyses}

The tourmaline single crystals and crystal fragments used for the structure refinements were prepared as a section (polished on one side of the samples) for chemical analysis. Concentrations of all elements except B, Li, Be and $\mathrm{H}$ were determined with a Cameca SX51 electron microprobe equipped with five wavelength-dispersive spectrometers (Universität Heidelberg). Operating conditions were $15 \mathrm{kV}$ accelerating voltage, $20 \mathrm{nA}$ beam current, $5 \mathrm{~mm}$ beam diameter, PAP data-reduction routine. Peaks for all elements were measured for $10 \mathrm{~s}$, except for $\operatorname{Mg} K \alpha$ (20 s), $\operatorname{Cr} K \alpha(20 \mathrm{~s}), \operatorname{Ti} K \alpha(20 \mathrm{~s})$, $\mathrm{Zn} K \alpha(30 \mathrm{~s})$, and $\mathrm{F} K \alpha(40 \mathrm{~s})$. Because the $\mathrm{F} K \alpha$ line interferes with the $\mathrm{Fe}$ and $\mathrm{Mn} L \alpha$ lines, the measured $\mathrm{F}$ values require a correction, which is described in detail by Ertl et al. (2009). We used the following standards and $\mathrm{X}$-ray lines for calibration: albite $(\mathrm{NaK} \alpha)$, periclase $(\mathrm{Mg} K \alpha)$, corundum $(\mathrm{Al} K \alpha)$, wollastonite $(\mathrm{Si} K \alpha)$, rutile $(\mathrm{Ti} K \alpha)$, eskolaite $(\mathrm{Cr} K \alpha)$, scapolite $(\mathrm{Cl} K \alpha)$, orthoclase
$(\mathrm{K} K \alpha)$, wollastonite $(\mathrm{Ca} K \alpha)$, hematite $(\mathrm{Fe} K \alpha)$, rhodonite $(\mathrm{Mn} K \alpha)$, gahnite $(\mathrm{Zn} K \alpha)$, and topaz $(\mathrm{F} K \alpha)$.

Concentrations of $\mathrm{H}, \mathrm{Li}, \mathrm{Be}$ and $\mathrm{B}$ were determined by SIMS with a CAMECA IMS $3 f$ ion microprobe (Universität Heidelberg). For Li, Be, and B the primary beam current was $10 \mathrm{nA}$, resulting in a beam diameter of $\sim$ $20 \mu \mathrm{m}$. The spectrometer mass resolution $\mathrm{M} / \Delta \mathrm{M}$ was set to $\sim 1100( \pm 10 \%)$ and the imaged field was $150 \mu \mathrm{m}$ in diameter. For determination of $\mathrm{H}$, the primary beam current was $20 \mathrm{nA}, \mathrm{M} / \Delta \mathrm{M}$ was set to $\sim 400( \pm 10 \%)$ and the imaged field was set to $25 \mu \mathrm{m}$ (nominal value). To reduce the influence of in situ contamination with water, a small field-aperture $(d=400 \mu \mathrm{m})$ was chosen, which limited the analysed area to $\sim 5 \mu \mathrm{m}$ in diameter. The relative ion yield for $\mathrm{B}$ and $\mathrm{H}$ was determined using three tourmalines as reference material: elbaite (98144), dravite (108796) and schorl (112566) (Dyar et al., 1998). For Li and Be the standard glass SRM610 (NIST) was used as reference material (more analytical details are given in Ertl et al., 2009). Because matrix effects and the uncertainty on element concentrations in the reference materials limit the accuracy, the worst-case deviation is estimated to be better than $20 \%$ for $\mathrm{H}$ and $\mathrm{Li}$ and better than $10 \%$ for Be and $\mathrm{B}$.

Table 4 contains complete chemical-analytical data for the tourmalines. The crystal-chemical formula was calculated on the basis of $31(\mathrm{OH}, \mathrm{O}, \mathrm{F})$. When the amount of $\mathrm{B}$ in the preliminary calculated formulae (by using the SIMS 
data) was below 3.00 atoms per formula unit (apfu), $\mathrm{B}_{2} \mathrm{O}_{3}$ was calculated to fill up the $\mathrm{B}$ site completely with $\mathrm{B}$. If the sum $(\mathrm{OH}+\mathrm{F})$ was significantly too high $(>4.0 \mathrm{apfu})$ when using the measured $\mathrm{H}_{2} \mathrm{O}$ content, $\mathrm{H}_{2} \mathrm{O}$ was calculated for $(\mathrm{OH}+\mathrm{F})=4.0$.

\subsection{Mössbauer spectroscopy}

Approximately $10 \mathrm{mg}$ of each tourmaline sample from the Erzgebirge were gently crushed under acetone, then mixed with a sugar-acetone solution designed to form sugar

Table 4. Composition of type fluor-schorl from Grasstein, South Tyrol, Italy and Zschorlau, Saxony, Germany, and of fluor-schorl and schorl from other localities in the Erzgebirge (wt $\%) . n=$ number of EMP analyses averaged. Formulae calculated on the basis of $31(\mathrm{O}, \mathrm{OH}, \mathrm{F})$.

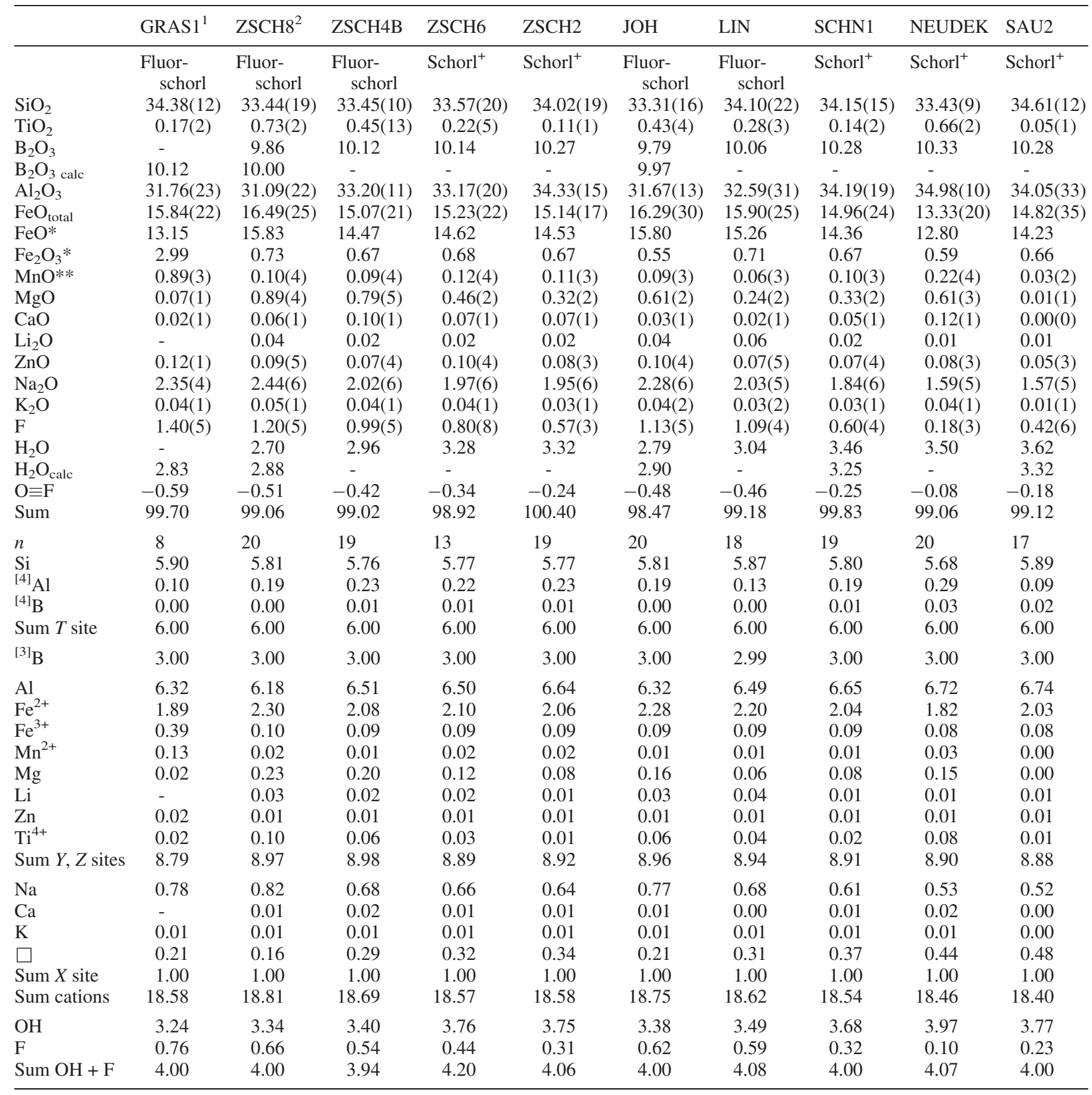

Notes: ${ }^{1}$ Fluor-schorl (type material) from Grasstein, South-Tyrol, Italy (data from Ertl et al., 2006); ${ }^{2}$ Fluor-schorl (type material) from Zschorlau, Saxony, Germany. ${ }^{+}$Schorl from cotype localities for schorl in the Erzgebirge (Novák et al., 2009; Henry et al., 2010). Localities as indicated in text (Introduction). $\mathrm{Cr}_{2} \mathrm{O}_{3}$ and $\mathrm{Cl}$ are below detection limit (b.d.) in all samples. SIMS data: one analyis for $\mathrm{B}_{2} \mathrm{O}_{3}$, $\mathrm{Li}_{2} \mathrm{O}, \mathrm{H}_{2} \mathrm{O}$, and for Be (ZSCH2, 80 ppm; ZSCH4B, ZSCH6, ZSCH8, 10 ppm; SCHN1, 50 ppm; JOH, LIN, NEUDEK, SAU2, b.d.). For some samples was $\mathrm{B}_{2} \mathrm{O}_{3}$ calc calculated for $B=3.00$ apfu and $\mathrm{H}_{2} \mathrm{O}_{\text {calc }}$ for $(\mathrm{OH})+\mathrm{F}=4.00$ apfu. * FeO and $\mathrm{Fe}_{2} \mathrm{O}_{3}$ were recalculated by using Mössbauer spectroscopy data (see Table 5; for GRAS1 see Ertl et al., 2006; for NEUDEK the average Fe ${ }^{3+}$ value of the investigated Erzgebirge samples was used: $4 \% \mathrm{Fe}^{3+}$ ). ** Total $\mathrm{Mn}$ as $\mathrm{MnO}$. If a calculated value is given in the analysis part, then this value is used for the total sum and formula calculations. The measured values for $\mathrm{B}_{2} \mathrm{O}_{3}$ and $\mathrm{H}_{2} \mathrm{O}$ agree within $\sim 1-2 \%$ and $\sim 4-8 \%$, respectively, with the calculated values. 
coatings around each grain and prevent preferred orientation. Grains were heaped in a sample holder confined by Kapton polyimide film tape. Mössbauer spectra were acquired at $295 \mathrm{~K}$ using a $40 \mathrm{mCi}{ }^{57} \mathrm{Co}$ in $\mathrm{Rh}$ source on a WEB Research Co. model WT302 spectrometer (Mount Holyoke College) and corrected to remove the fraction of the baseline due to the Compton scattering of $122 \mathrm{keV}$ gamma rays by electrons inside the detector. Run times were $24 \mathrm{~h}$ with baseline counts of 9 and 32 million. Spectra were collected in 2048 channels and corrected for nonlinearity. Data were modelled using a programme from the University of Ghent, Belgium, called DIST_3E (an implementation of software described in Wivel \& Mørup, 1981), which uses model-independent quadrupole splitting distributions for which the subspectra are constituted by Lorentzian-shaped lines. Peak areas were not corrected for differential recoil-free fractions for $\mathrm{Fe}^{2+}$ and $\mathrm{Fe}^{3+}$ because the appropriate correction factors do not exist.

Mössbauer spectra for cotype fluor-schorl from Grasstein are given in Ertl et al. (2006).

\subsection{Optical and near-infrared absorption spectroscopy}

Fluor-schorl (sample GRR 2935) from Grasstein, South Tyrol, Italy, was prepared for optical absorption spectroscopy as a polished thin section, $0.045 \mathrm{~mm}$ thick, oriented with the $c$ axis in the plane of the section. Optical and nearIR absorption spectra in the $300-1500 \mathrm{~nm}$ range were obtained on a homemade diode array spectrometer described in Taran \& Rossman (2001). Spectra in the 1400-2200 nm range were obtained on a Nicolet Magna 860 FTIR with $\mathrm{a} \mathrm{CaF}_{2}$ beamsplitter, InGaAs detector, and a $\mathrm{LiIO}_{3}$ crystal polarizer.

\subsection{Raman spectroscopy}

Single-crystal Raman spectra of fluor-schorl and schorl, both from Zschorlau, were recorded from randomly oriented fragments. The spectra were obtained in quasibackscatter geometry by means of a Horiba LabRAM-HR spectrometer equipped with a Olympus BX41 optical microscope. The $532 \mathrm{~nm}$ emission $(10 \mathrm{~mW})$ of a frequency-doubled Nd:YAG laser was used for excitation. The wavenumber accuracy was $0.5 \mathrm{~cm}^{-1}$. With a grating with 1800 lines per millimetre in the optical pathway, the spectral resolution was $\sim 1 \mathrm{~cm}^{-1}$. More experimental details are described elsewhere (Ruschel et al., 2012).

\section{Results}

\subsection{Optical properties, optical absorption spectra and Raman spectra}

In plane-polarized light, fluor-schorl is dichroic, $O=$ brown to grey-brown (Zschorlau), blue (Grasstein), $E=$ pale grey-brown (Zschorlau), cream (Grasstein). Fluor-

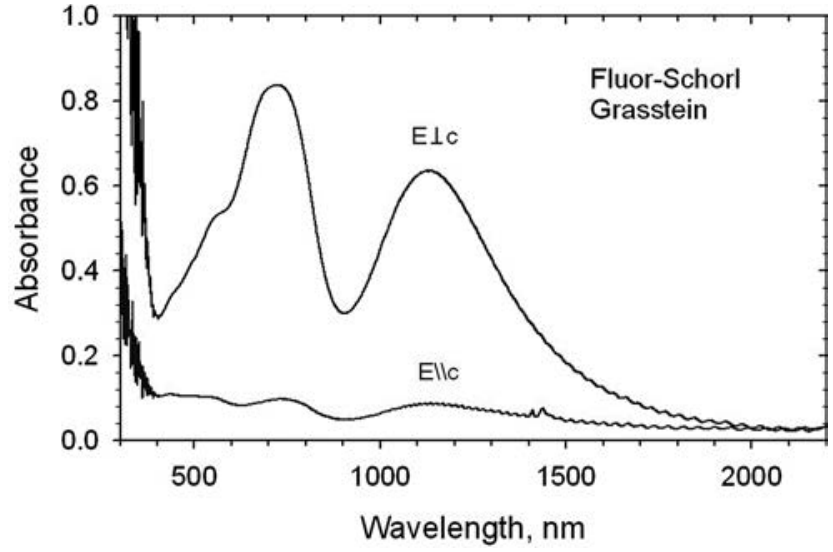

Fig. 1. Optical absorption spectra of fluor-schorl from Grasstein, South Tyrol, Italy.

schorl is uniaxial negative, $\omega=1.660(2)-1.661(2), \varepsilon=$ 1.636(2)-1.637(2). The salient feature of the optical absorption spectrum (Fig. 1) is a pair of absorption bands in the $\mathbf{E} \perp c$ direction centred at about 732 and $1140 \mathrm{~nm}$. These are $\mathrm{Fe}^{2+}$ absorptions with intensity enhanced in the $\mathbf{E} \perp c$ direction by interaction with $\mathrm{Fe}^{3+}$ (Mattson \& Rossman, 1987). This is consistent with the amount of $\mathrm{Fe}^{3+}$ determined by the chemical analysis. A shoulder at $530 \mathrm{~nm}$ is in a region where a $\mathrm{Fe}^{2+}$ spin-forbidden band occurs as well as close to where $\mathrm{Mn}^{3+}$ features occur. A weak, sharper feature at $496 \mathrm{~nm}$ is a $\mathrm{Fe}^{2+}$ spin-forbidden band (Faye et al., 1968). In addition, overtones of the $\mathrm{OH}$ stretching are observed at 1408 and $1435 \mathrm{~nm}$ in the Ellc orientation.

Raman spectra of fluor-schorl and schorl, both from Zschorlau, are presented in Fig. 2. Spectra are shown as recorded, i.e. no background correction or smoothing was applied. As expected, the fingerprint pattern of vibrational modes of fluor-schorl corresponds closely to spectra of tourmalines of the buergerite-schorl series (Gasharova

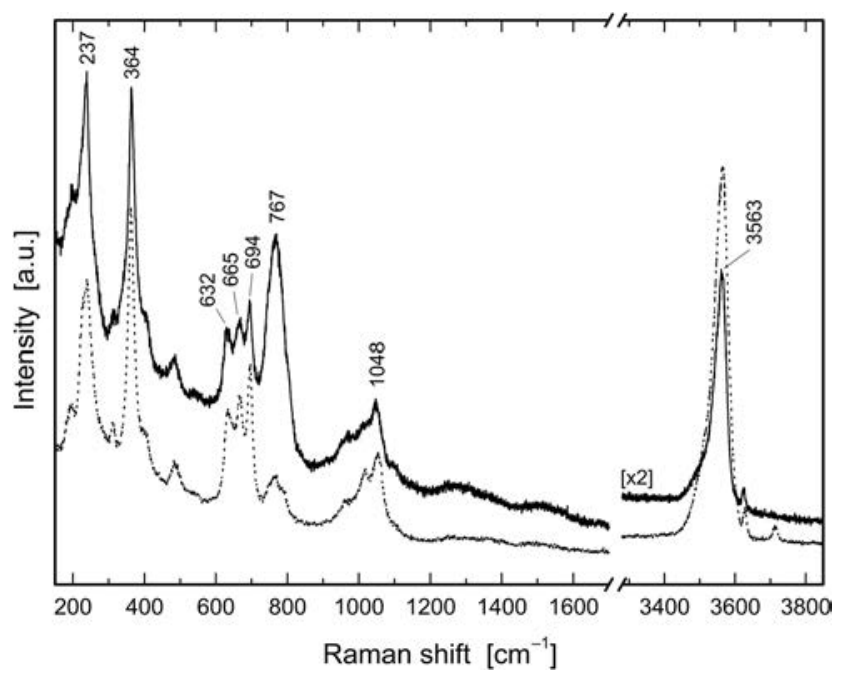

Fig. 2. Raman spectra of fluor-schorl (solid line) and schorl (dotted line), both from Zschorlau, Saxony, Germany. 
et al., 1997). The main difference between Raman spectra of fluor-schorl and schorl is observed in the high-energy spectral range, where fluor-schorl is characterized by generally lower intensity of the $\mathrm{O}-\mathrm{H}$ stretching band at 3563 $\mathrm{cm}^{-1}$. This is explained by the fact that the amount of $\mathrm{OH}$ present in fluor-schorl is visibly lower, compared to schorl. Note, however, that our observation is rather qualitative since no precise quantification of the hydroxyl content based on our Raman spectra was possible (this would require measurement in oriented sections and the availability of a proper calibration; see e.g. Thomas et al., 2008).

\subsection{Physical properties}

Fluor-schorl is brittle and has a Mohs hardness of 7; it is non-fluorescent, has no observable parting and a poor/ indistinct cleavage parallel to $\{0001\}$. It has a measured density of $3.20(3) \mathrm{g} / \mathrm{cm}^{3}$ (by pycnometry) and a calculated density of $3.235 \mathrm{~g} / \mathrm{cm}^{3}$ (Zschorlau) and $3.218 \mathrm{~g} / \mathrm{cm}^{3}$ (Grasstein) from the empirical formulae. The fracture is irregular to uneven and sub-conchoidal. It has a prismatic habit and shows the forms $\{120\},\{-100\}$ (usually not clearly differentiated because of strong striation parallel to the $c$ axis) and rarely $\{101\}$. Twinning was not observed. The $c: a$ ratio calculated from the refined unit-cell parameters (powder data) is 0.449 (Zschorlau) and 0.448 (Grasstein).

\subsection{Mössbauer spectra}

The Mössbauer spectrum of fluor-schorl from Grasstein was fit to four doublets (Ertl et al., 2006), using as guidelines the Mössbauer parameters in Dyar et al. (1998). The first two doublets are subcomponents of a distribution corresponding to $\mathrm{Fe}^{2+}$ at the $Y$ site. The third doublet, with an isomer shift of $0.87 \mathrm{~mm} / \mathrm{s}$, lies in the range for electron delocalized peaks, reflecting an electron shared between $\mathrm{Fe}^{2+}$ and $\mathrm{Fe}^{3+}$. Thus, the doublet area must be split between the two valence states. Finally, the last distribution, with an isomer shift of $0.37 \mathrm{~mm} / \mathrm{s}$, represents $\mathrm{Fe}^{3+}$ in octahedral coordination. A specific site assignment for $\mathrm{Fe}^{3+}$ could not be made on the basis of the Mössbauer data alone. Based on these data, Ertl et al. (2006) concluded that the Grasstein sample contains $17 \%$ of the total $\mathrm{Fe}$ as $\mathrm{Fe}^{3+}$, with an error of $\pm 5 \%$ due to the significant overlap of the peaks in the spectrum and the additional uncertainty introduced by assuming the same recoil-free fraction for $\mathrm{Fe}^{2+}$ and $\mathrm{Fe}^{3+}$.

The Mössbauer spectra of fluor-schorl and schorl from the Erzgebirge area were fit to five doublets (Table 5; Figs S1-S4, available online as Supplementary Material linked to this article on the GSW website of the journal, http://eurjmin.geoscienceworld.org/). The first four doublets are subcomponents of a distribution corresponding to $\mathrm{Fe}^{2+}$ at the $Y$ site. The fifth doublet, with an isomer shift of $0.42-0.46 \mathrm{~mm} / \mathrm{s}$, represents $\mathrm{Fe}^{3+}$ in octahedral

Table 5. Mössbauer parameters for fluor-schorl and schorl from the Erzgebirge.

\begin{tabular}{|c|c|c|c|c|c|}
\hline $\begin{array}{l}\text { Locality } \\
\text { Sample\# }\end{array}$ & & $\frac{\text { Zschorlau }}{\text { ZSCH }}$ & $\frac{\text { Johanngeorgenstadt }}{\mathrm{JOH}}$ & $\frac{\text { Schneeberg }}{\text { SCHN1 }}$ & $\begin{array}{l}\text { Sauberg Mine } \\
\text { SAU2 }\end{array}$ \\
\hline${ }^{[\mathrm{Y} 1]} \mathrm{Fe}^{2+}$ & $\begin{array}{l}\delta, \mathrm{mm} / \mathrm{s} \\
\Delta, \mathrm{mm} / \mathrm{s} \\
\Gamma, \mathrm{mm} / \mathrm{s} \\
\% \text { Area }\end{array}$ & $\begin{array}{l}1.09 \\
2.48 \\
0.26 \\
31\end{array}$ & $\begin{array}{l}1.10 \\
2.48 \\
0.26 \\
27\end{array}$ & $\begin{array}{l}1.09 \\
2.48 \\
0.26 \\
32\end{array}$ & $\begin{array}{l}1.10 \\
2.49 \\
0.26 \\
31\end{array}$ \\
\hline${ }^{[\mathrm{Y} 3]} \mathrm{Fe}^{2+}$ & $\begin{array}{l}\delta, \mathrm{mm} / \mathrm{s} \\
\Delta, \mathrm{mm} / \mathrm{s} \\
\Gamma, \mathrm{mm} / \mathrm{s} \\
\% \text { Area }\end{array}$ & $\begin{array}{l}1.04 \\
1.74 \\
0.26 \\
8\end{array}$ & $\begin{array}{l}1.08 \\
1.70 \\
0.26 \\
10\end{array}$ & $\begin{array}{l}1.06 \\
1.72 \\
0.26 \\
9\end{array}$ & $\begin{array}{l}1.10 \\
1.85 \\
0.26 \\
14\end{array}$ \\
\hline${ }^{[\mathrm{Y} \text { or } \mathrm{Z}]} \mathrm{Fe}^{3+}$ & $\begin{array}{l}\delta, \mathrm{mm} / \mathrm{s} \\
\Delta, \mathrm{mm} / \mathrm{s} \\
\Gamma, \mathrm{mm} / \mathrm{s} \\
\% \text { Area }\end{array}$ & $\begin{array}{l}0.44 \\
0.45 \\
0.30 \\
4\end{array}$ & $\begin{array}{l}0.46 \\
0.45 \\
0.30 \\
3\end{array}$ & $\begin{array}{l}0.45 \\
0.43 \\
0.30 \\
4\end{array}$ & $\begin{array}{l}0.42 \\
0.43 \\
0.26 \\
4\end{array}$ \\
\hline$\chi^{2}$ & & 2.80 & 1.32 & 1.86 & 1.65 \\
\hline Total $\mathrm{Fe}^{3+}(\%)$ & & 4 & 3 & 4 & 4 \\
\hline
\end{tabular}

Notes: Results are given in $\mathrm{mm} / \mathrm{s}$ relative to the center point of a Fe foil calibration spectrum.

$\Gamma=$ the Lorentzian peak-width at half-maximum, $\delta=$ isomer shift, $\Delta=$ quadrupole splitting. Mössbauer parameters for fluor-schorl from Grasstein are given in Ertl et al. (2006). 
coordination. Also for this amount of $\mathrm{Fe}^{3+}$ no specific site assignment could be made alone on the basis of these Mössbauer data. Interestingly, the $\mathrm{Fe}^{3+}$ content is quite similar for all investigated schorl and fluor-schorl samples from the Erzgebirge area ( 3-4\% of the total Fe; Table 5). The errors on $\% \mathrm{Fe}^{3+}$ contents of samples as measured by Mössbauer spectroscopy are generally cited as $\pm 1-3 \%$ absolute for tourmaline (e.g. Dyar et al., 1998). However, the spectra in this study are of extremely high quality as shown by the very small standard uncertainties (Figs S1-S4) and the results for total ferric iron are strikingly consistent. Thus, we estimate that the $\% \mathrm{Fe}^{3+}$ values in this study are more accurate than those used in the Dyar et al. (1998) study, and are probably within $\pm 2 \%$ accuracy.

\subsection{Crystal chemistry and structure analysis}

Analyses by a combination of electron microprobe, SIMS, Mössbauer spectroscopic data and crystal-structure refinement result in the structural formulae ${ }^{X}\left(\mathrm{Na}_{0.82} \mathrm{~K}_{0.01} \mathrm{Ca}_{0.01}\right.$ $\left.\square_{0.16}\right)^{Y}\left(\mathrm{Fe}^{2+}{ }_{2.30} \mathrm{Al}_{0.38} \mathrm{Mg}_{0.23} \mathrm{Li}_{0.03} \mathrm{Mn}^{2+}{ }_{0.02} \mathrm{Zn}_{0.01} \square_{0.03}\right)_{\Sigma 3.00}$ $\left.Z_{(} \mathrm{Al}_{5.80} \mathrm{Fe}^{3+}{ }_{0.10} \mathrm{Ti}^{4+}{ }_{0.10}\right){ }^{T}\left(\mathrm{Si}_{5.81} \mathrm{Al}_{0.19} \mathrm{O}_{18}\right) \quad\left(\mathrm{BO}_{3}\right)_{3}{ }^{V}(\mathrm{OH})_{3}$ ${ }^{W}\left[\mathrm{~F}_{0.66}(\mathrm{OH})_{0.34}\right]$ (cotype material from Zschorlau) and ${ }^{X}\left(\mathrm{Na}_{0.78} \mathrm{~K}_{0.01} \square_{0.21}\right) \quad{ }^{Y}\left(\mathrm{Fe}^{2+}{ }_{1.89} \mathrm{Al}_{0.58} \mathrm{Fe}^{3+}{ }_{0.13} \mathrm{Mn}^{2+}{ }_{0.13} \mathrm{Ti}^{4+}{ }_{0.02}\right.$

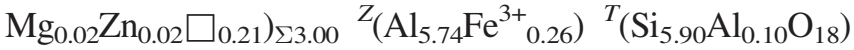
$\left(\mathrm{BO}_{3}\right)_{3}{ }^{V}(\mathrm{OH})_{3}{ }^{W}\left[\mathrm{~F}_{0.76}(\mathrm{OH})_{0.24}\right]$ (cotype material from Grasstein). Fluor-schorl is rhombohedral, space group $R 3 m, a=16.005(2), c=7.176(1) \AA, V=1591.9(4) \AA^{3}$ (Zschorlau), $a=15.995(1), c=7.166(1) \AA, V=1587.7(9)$ $\AA^{3}$ (Grasstein), $Z=3$. The Flack parameters of all samples demonstrate that no racemic twinning is present. The eight strongest observed X-ray diffraction lines in the powder pattern $[d$ in $\AA(I) h k l]$ are: $2.584(100)(051), 3.469(99)$ $(012), \quad 2.959(83)(122), \quad 2.044(80)(152), \quad 4.234(40)(211)$, 4.005(39)(220), 6.382(37)(101), 1.454(36)(514) (Grasstein). Unit-cell parameters estimated by using powder data (Table S1, deposited and freely available online, linked to this article on the GSW website of the journal http://eurjmin.geoscienceworld.org) and Rietveld refinement (Fischer et al., 1993) are $a=15.996(1), c=7.186(1) \AA, V=1592.4(9) \AA^{3}$ (Zschorlau) and $a=15.995(1), c=7.166(1) \AA, V=$ 1587.7(9) $\AA^{3}$ (Grasstein).

\section{5. $X$-site occupancy}

The $X$ site is in both cotype specimens of fluor-schorl mainly occupied by $\mathrm{Na}(0.78-0.82 \mathrm{apfu})$ and only very small amounts of $\mathrm{K}$ and $\mathrm{Ca}(\leq 0.01 \mathrm{apfu}$; Table 4$)$. The $X$ site vacancies are in the range $0.16-0.21 \mathrm{pfu}$. In all five investigated fluor-schorl samples, the $\mathrm{Na}$ content varies between 0.68 and 0.82 apfu (Table 4), whereas the $\mathrm{K}$ and $\mathrm{Ca}$ contents are very low $(\leq 0.02 \mathrm{apfu})$. The $X$-site vacancies are in the range $0.16-0.31 \mathrm{pfu}$.

In the schorl samples from the cotype localities, $\mathrm{Na}$ varies from 0.52 to 0.66 apfu (Table 4 ), while the $\mathrm{K}$ and $\mathrm{Ca}$ contents are also very low ( $\leq 0.02 \mathrm{apfu})$. The numbers of vacancies are somewhat higher than in the investigated fluor-schorl samples (0.32-0.48 pfu).

\section{6. $Y$ - and $Z$-site occupancy}

The $Y$ site is in both fluor-schorl samples of the cotype localities mainly occupied by $\mathrm{Fe}^{2+}(\sim 1.9-2.3$ apfu; Table 4) and only by small amounts of $\mathrm{Fe}^{3+}(\leq 0.1 \mathrm{apfu})$, which is consistent with the relatively large $\langle Y-\mathrm{O}\rangle$ distances (2.056-2.058 A; Table 3). Also significant amounts of Al occupy the $Y$ site ( $c a .0 .4-0.6 \mathrm{apfu})$. The amounts of $\mathrm{Mg}(\leq 0.2 \mathrm{apfu})$ and $\mathrm{Mn}^{2+}(\leq 0.1 \mathrm{apfu})$ are relatively small. Very small amounts of $\mathrm{Zn}, \mathrm{Li}$ and $\mathrm{Ti}^{4+}$ were also observed $(\leq 0.03 \mathrm{apfu})$. The estimated $Y$-site vacancies are relatively minor $(\leq 0.2 \mathrm{pfu})$. The $Z$ site is in these fluor-schorl samples mainly occupied by $\mathrm{Al}(\sim 5.7-5.8 \mathrm{apfu})$. We assigned small amounts of $\mathrm{Fe}^{3+}$ in the range of $\sim 0.1-0.3$ apfu to the $Z$ site, in accordance with refined site occupancies $(<Z-O>=1.920-1.921 \AA$; see also Ertl et al., 2012). Because the assignment of $\mathrm{Ti}^{4+}$ to the $Z$ site was strongly supported by bond-valence calculations in Ertl et al. (2012), we assigned also small amounts of $\mathrm{Ti}^{4+}(\leq 0.1$ apfu) to this site. The finally assigned $Z$-site occupation of these fluor-schorl samples is consistent with the refined $Z$-site occupancy within the $3 \sigma$ error (Table 2, this work and Ertl et al., 2006), and with the estimated $\mathrm{Fe}^{3+}$ of the Mössbauer data, also within errors.

Fluor-schorl samples from the Erzgebirge (Saxony, Germany, and Krušné Hory Mts., Bohemia, Czech Republic) contain $\mathrm{Fe}^{2+}$ in the range $\sim 2.1-2.3$ apfu (Table 4) and relatively small amounts of $\mathrm{Fe}^{3+}(\sim 0.1 \mathrm{apfu})$. Interestingly, Mössbauer data shows that the ferric component is in all Erzgebirge localities very similar $\left(\sim 3-4 \% \mathrm{Fe}^{3+}\right.$; Table 5; Figs. S1-S4). In addition, these fluor-schorls contain relatively small amounts of $\mathrm{Mg}(\sim 0.1-0.2$ apfu $)$ and $\mathrm{Ti}^{4+}$ $(\leq 0.1 \mathrm{apfu})$, as well as very small amounts of $\mathrm{Li}(\leq 0.04$ apfu), $\mathrm{Mn}^{2+}$ (0.01-0.02 apfu) and Zn (0.01 apfu; Table 4).

Schorl samples from the cotype localities (for schorl) in the Erzgebirge contain lower amounts of $\mathrm{Fe}^{2+}(\sim 1.8-2.1$ apfu), similar amounts of $\mathrm{Fe}^{3+}\left(\sim 0.1\right.$ apfu; $\sim 4 \% \mathrm{Fe}^{3+}$; Table 5), relatively small amounts of $\mathrm{Mg}(\leq 0.15 \mathrm{apfu})$ and $\mathrm{Ti}^{4+}(\leq 0.08$ apfu $)$ and very small amounts of $\mathrm{Mn}^{2+}$ (0.01-0.03 apfu), Li (0.01-0.02 apfu) and Zn (0.01 apfu; Table 4).

\section{7. $T$-site occupancy}

The $T$ site in the cotype samples of fluor-schorl is mainly occupied by $\mathrm{Si}$ and contains relatively small amounts of $\mathrm{Al}$ $(\sim 0.1-0.2 \mathrm{apfu})$, consistent with slightly enlarged $<T-\mathrm{O}>$ distances in the range 1.621-1.622 $\AA$ (Table 3 ) and data given by MacDonald \& Hawthorne (1995) on the $\mathrm{Si} \leftrightarrow \mathrm{Al}$ substitution in tourmaline. In fluor-schorl samples from the Erzgebirge the $<T-\mathrm{O}>$ distances vary from 1.620 to 1.623 A (Table 3).

Schorl samples from the cotype localities (for schorl) in the Erzgebirge exhibit $\sim 0.2-0.3$ apfu ${ }^{[4]} \mathrm{Al}$, consistent with $<T-\mathrm{O}>$ distances in the range 1.622-1.623 $\AA$ (Table 3 ). 


\section{8. $V$ - and $W$-site occupancy}

The $V$ site is in all investigated samples completely occupied by $\mathrm{OH}$. The $W$ site of the fluor-schorl samples from the cotype localities is occupied by $\sim 0.7-0.8$ apfu $\mathrm{F}$ (Table 4), and the remainder of the $W$ site seems to be occupied by $\mathrm{OH}$. Fluor-schorl from the Erzgebirge contains $0.54-0.66$ apfu $\mathrm{F}$ and $\mathrm{OH}$ in the range $\sim 0.3-0.5 \mathrm{pfu}$ (Table 4). There is no evidence for the presence of any significant $\mathrm{O}$ (without $\mathrm{H}$ ) at the $W$ site.

Schorl from the cotype localities (for schorl) in the Erzgebirge contains $\sim 0.6-0.9 \mathrm{pfu} \mathrm{OH}$ at the $W$ site. The amount of $\mathrm{F}$ is in the range of $\sim 0.1-0.4$ apfu (Table 4). Again there is no evidence for any significant amounts of $\mathrm{O}$ (without $\mathrm{H}$ ) at the $W$ site.

\section{Discussion}

The $X$-site vacancy and the $\mathrm{F}$ content of all investigated samples are inversely correlated $\left(r^{2}=0.83\right)$. Similar correlations have been observed by Ertl et al. (2009, 2010). When $\mathrm{OH}$ occupies the $W$ site, the $\mathrm{H}$ atom points toward the $X$ site. Crystallographic studies proved that $\mathrm{F}$ is found exclusively at the $W$ site (as summarized by Henry \& Dutrow, 1996). The presence or absence of $F$ immediately adjacent to the $\mathrm{XO}_{9}$ polyhedron thus may affect this polyhedron. Henry (2005) and Henry \& Dutrow (2011) showed in an evaluation of a large amount of chemical analyses of different tourmalines that, with more than $0.5 X$-site vacancies, there is little or no $\mathrm{F}$ present in tourmaline.

By comparing the $X-\mathrm{O} 2, X-\mathrm{O} 4$ and $X-\mathrm{O} 5$ bond lengths $(X-\mathrm{O} 2<X-\mathrm{O} 5<X-\mathrm{O} 4)$ of different tourmaline structures, it is evident that the $X-\mathrm{O} 2$ bond length has the widest variation compared to the $X-\mathrm{O} 4$ and $X-\mathrm{O} 5$ distances (see Table 3). In addition, being the shortest, the $X-\mathrm{O} 2$ bond length effectively reflects the mean ionic radius of the $X$-site occupants (Ertl et al., 2001). By plotting the $X-\mathrm{O} 2$ distance and $\mathrm{F}$ of all investigated samples, a strong inverse correlation was observed $\left(r^{2}=0.92\right.$; Fig. 3$)$.

Tourmalines of the fluor-schorl - schorl solid-solution series show a strong positive correlation between the $\mathrm{F}$ content and the $\langle Y-\mathrm{O}\rangle$ distance $\left(r^{2}=0.93\right.$; Fig. 4). Because the $\langle Y-\mathrm{O}\rangle$ in these samples is mainly governed by the $\mathrm{Fe}^{2+}$ content, $\mathrm{Fe}^{2+}$-rich tourmalines clearly tend to have a F-rich or F-dominant composition, which is in agreement with our general observation. A further strong positive correlation was found between the refined $\mathrm{F}$ content and the $Y-W$ distance (Fig. 5). If the F content cannot be refined (for example, because only low-resolution and/ or low-quality diffraction data are available, the refined $Y-W$ distance may be used to obtain a quick and fairly accurate estimate of the $\mathrm{F}$ content.

The $\mathrm{F}$ content in individual tourmaline crystals may vary, as shown by EMPA traverses measured across a euhedral black tourmaline crystal (cut perpendicular to the $c$ axis) from Zschorlau, Erzgebirge, $\sim 5 \mathrm{~mm}$ in diameter. The crystal core area can be assigned to schorl (with

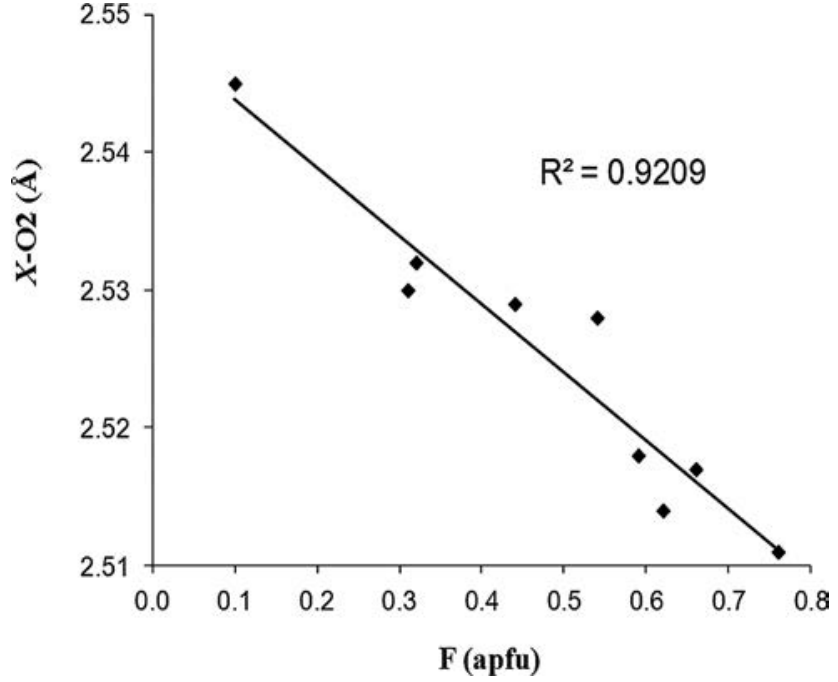

Fig. 3. Correlation between $\mathrm{F}$ and $\mathrm{X}-\mathrm{O} 2$ distance in tourmalines of the fluor-schorl - schorl solid solution. All samples from this work are plotted.

$\sim 0.6 \mathrm{wt} \% \mathrm{~F})$, while the rim area can be assigned to fluorschorl ( $\sim 1.0 \mathrm{wt} \% \mathrm{~F})$. During tourmaline crystallization F, $\mathrm{Fe}, \mathrm{Mg}, \mathrm{Ti}$, and $\mathrm{Na}$ increase significantly, while $\mathrm{Si}$ and $\mathrm{Al}$ decrease. Such a zoning seems to be quite common for black $\mathrm{Fe}^{2+}$-rich tourmalines from the Erzgebirge. Such relatively high amounts of $\mathrm{F}$ (up to $\sim 0.7 \mathrm{apfu}$ ), ${ }^{[4]} \mathrm{Al}$ (up to $0.26 \mathrm{apfu}$ ) and relatively low $X$-site vacancies (down to $0.15 \mathrm{pfu}$ ) usually only occur in tourmalines from highgrade metapelites (Henry \& Dutrow, 1996). In contrast, the earlier crystallized schorl exhibits relatively high numbers of $X$-site vacancies (up to $\sim 0.5 \mathrm{pfu}$ ) and lower $\mathrm{F}$

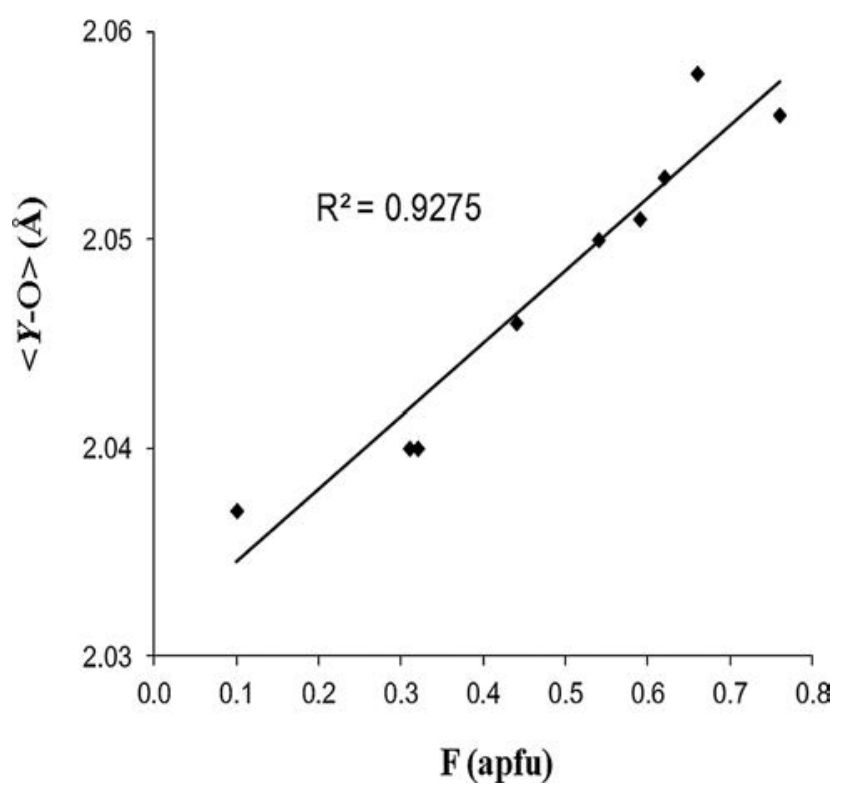

Fig. 4. Correlation between $\mathrm{F}$ and $\langle Y-\mathrm{O}\rangle$ distance in tourmalines of the fluor-schorl - schorl solid solution. All samples from this work are plotted. 


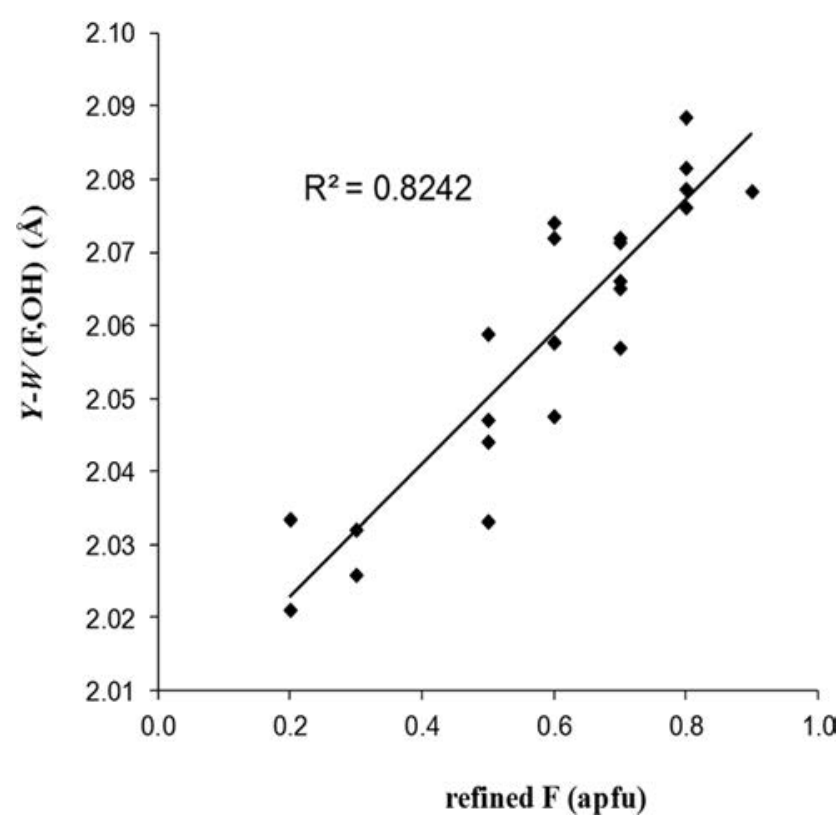

Fig. 5. Correlation between the refined $\mathrm{F}$ content and the $Y-W(\mathrm{~F}, \mathrm{OH})$ distance. Both all samples from this work and additional fluor-schorl (Section 4) and schorl (unpublished) samples are plotted.

contents. The fluor-schorl rim seems to have grown during increasing temperatures under pneumatolytic conditions in the presence of pneumatolytic fluids.

\section{Conclusion}

Fluor-schorl, ideally $\mathrm{NaFe}^{2+}{ }_{3} \mathrm{Al}_{6} \mathrm{Si}_{6} \mathrm{O}_{18}\left(\mathrm{BO}_{3}\right)_{3}(\mathrm{OH})_{3} \mathrm{~F}$, is related to end-member schorl by the substution $\mathrm{F} \rightarrow$ $(\mathrm{OH})$. Fluor-schorl is named for being the $\mathrm{F}$-analogue of schorl, $\mathrm{NaFe}_{3}^{2+}{ }_{3} \mathrm{Al}_{6} \mathrm{Si}_{6} \mathrm{O}_{18}\left(\mathrm{BO}_{3}\right)_{3}(\mathrm{OH})_{3}(\mathrm{OH})$, in accordance with the IMA-approved revised nomenclature of the tourmaline supergroup (Novák et al., 2009; Henry et al., 2010). Within the tourmaline supergroup, fluorschorl is also the $\mathrm{Fe}^{2+}$-analogue of fluor-dravite (Clark et al., 2011). It can be distinguished from schorl, dravite, fluor-dravite or other dark tourmalines only by accurate determination of the chemical composition, preferably by a combination of single-crystal structure refinements and chemical analyses. It may also be confused with luinaite(OH) (IMA 2009-046) and its currently unnamed F-analogue, both representing a distorted monoclinic variant $(\mathrm{Cm})$ of the tourmaline structure. Table 6 provides a comparison of relevant data for the rhombohedral members.

Our results demonstrate that fluor-schorl is relatively common in F-rich granites and granite pegmatites, especially in the Erzgebirge/Krušné Hory area, in which highly differentiated Li-mica granites (Förster et al., 1999; Romer et al., 2007) occur that contain melt inclusions with up to 11.2 wt.\% F (Müller et al., 2006). Further occurrences of fluor-schorl would be expected from similarly F-rich granite terrains (e.g., Cornwall, Andes).

For comparison purposes, we also studied samples of schorl from cotype localities in the Erzgebirge tin mining district, including Zschorlau (Ertl, 2006; Novák et al., 2009). The unit-cell parameters of schorl from these localities are slightly variable $[a=15.981-15.991(2), c=$ 7.146-7.162(1) $\AA$ ] , and overlap with the values determined for fluor-schorl. The corresponding structural formulae of these schorl samples vary from $\sim^{X}\left(\mathrm{Na}_{0.5} \square_{0.5}\right)^{Y}\left(\mathrm{Fe}^{2+}{ }_{1.8}\right.$ $\left.\mathrm{Al}_{0.9} \mathrm{Mg}_{0.2} \square_{0.1}\right) \quad \mathrm{Z}_{(}\left(\mathrm{Al}_{5.8} \mathrm{Fe}^{3+}{ }_{0.1} \mathrm{Ti}^{4+}{ }_{0.1}\right) \quad{ }^{T}\left(\mathrm{Si}_{5.7} \mathrm{Al}_{0.3} \mathrm{O}_{18}\right)$ $\left(\mathrm{BO}_{3}\right)_{3}{ }^{V}(\mathrm{OH})_{3}{ }^{W}\left[(\mathrm{OH})_{0.9} \mathrm{~F}_{0.1}\right]$ to $\sim^{X}\left(\mathrm{Na}_{0.7} \square 0.3\right)^{Y}\left(\mathrm{Fe}^{2+}{ }_{2.1}\right.$ $\left.\mathrm{Al}_{0.7} \mathrm{Mg}_{0.1} \square_{0.1}\right){ }^{Z}\left(\mathrm{Al}_{5.9} \mathrm{Fe}^{3+}{ }_{0.1}\right)^{T}\left(\mathrm{Si}_{5.8} \mathrm{Al}_{0.2} \mathrm{O}_{18}\right) \quad\left(\mathrm{BO}_{3}\right)_{3}$ ${ }^{V}(\mathrm{OH})_{3}{ }^{W_{[}}\left[(\mathrm{OH})_{0.6} \mathrm{~F}_{0.4}\right]$.

An investigation of black tourmalines from historical cotype localities for schorl (alluvial tin deposits and mines) in the Erzgebirge (Novák et al., 2009), originally listed by Mathesius (Mathesij, 1562), provided final proof for the occurrence of schorl, with the end-member formula $\mathrm{NaFe}_{3}^{2+} \mathrm{Al}_{6} \mathrm{Si}_{6} \mathrm{O}_{18}\left(\mathrm{BO}_{3}\right)_{3}(\mathrm{OH})_{3}(\mathrm{OH})$, in the Schneeberg District (Am Steinberg near Zschorlau and Schneeberg itself) and at Ehrenfriedersdorf (Sauberg Mine), both in Erzgebirge, Saxony, Germany, and at Nejdek, Krušné Hory Mountains, Bohemia, Czech Republic. The investigated tourmalines from the Erzgebirge show that there exists a complete fluor-schorl - schorl solid-solution series.

Table 6. Comparison of fluor-schorl, schorl and dravite data.

\begin{tabular}{llll}
\hline & Fluor-schorl & Schorl & Dravite \\
\hline Formula & $\mathrm{NaFe}_{3}{ }_{3} \mathrm{Al}_{6} \mathrm{Si}_{6} \mathrm{O}_{18}\left(\mathrm{BO}_{3}\right)_{3}(\mathrm{OH})_{3} \mathrm{~F}$ & $\mathrm{NaFe}^{2+}{ }_{3} \mathrm{Al}_{6} \mathrm{Si}_{6} \mathrm{O}_{18}\left(\mathrm{BO}_{3}\right)_{3}(\mathrm{OH})_{3}(\mathrm{OH})$ & $\mathrm{NaMg}_{3} \mathrm{Al}_{6} \mathrm{Si}_{6} \mathrm{O}_{18}\left(\mathrm{BO}_{3}\right)_{3}(\mathrm{OH})_{3}(\mathrm{OH})$ \\
Space group & $R 3 m$ & $R 3 m$ & $15.92-15.96$ \\
$a$ & $15.99-16.01$ & $15.93-15.99$ & $7.19-7.21$ \\
$c$ & $7.17-7.18$ & $7.15-7.16$ & $\sim 1590$ \\
$V$ & $\sim 1590$ & $\sim 1580$ & 3 \\
$Z$ & 3 & 3 & $2.574(100), 2.958(77), 3.979(75)$, \\
Five strongest lines in the & $3.995(100), 6.361(84), 2.584(76)$, & $2.579(100), 3.991(63), 2.952(61)$, & $4.218(61), 3.477(49)$ \\
$\quad$ powder pattern & $3.470(67), 4.225(39)$ & $4.220(58), 6.354(53)$ & $3.03-3.18,3.038$ \\
$D_{\text {meas }}, D_{\text {calc }}\left(\mathrm{g} / \mathrm{cm}^{3}\right)$ & $3.20(3), 3.24(1)$ & $3.18-3.22,3.244$ & $1.634-1.661$ \\
$\mathrm{n}_{\omega}$ & $1.661(2)$ & $1.660-1.672$ & $1.612-1.632$ \\
$\mathrm{n}_{\varepsilon}$ & $1.637(2)$ & $1.635-1.650$ & \\
\hline
\end{tabular}

* From Zschorlau. Schorl and dravite data from: this work, Bloodaxe et al. (1999); Ralph (2015a and b). 
Acknowledgements: We thank Jürgen Tschiedel (from Aue, Saxony, Germany; till 1953 "Geologengehilfe" in the Zschorlau mine, which was closed in 1956) for helpful information about the historical dumps at Am Steinberg, Zschorlau, Saxony, Germany. Further we thank Matthias Kreibich ("Besucherbergwerk Zinngrube Ehrenfriedersdorf"), Wolfgang Barsch ("Besucherbergwerk Vereinigt Zwitterfeld zu Zinnwald"), Gerhard and Alexandra Voges (Neufahrn bei Freising, Bayern, Germany) for tourmaline samples from the Erzgebirge, Saxony, Germany. Special thanks for helpful information and references to Stadtverwaltung Ehrenfriedersdorf (Archiv), Germany, and to Zschorlauer Gemeindeverwaltung, Zschorlau, Germany. We also thank Kurt Folie, Meran, Trentino-South Tyrol, Italy, and Matthias Hanke, Ottobeuren, Germany, for providing tourmaline samples from Trentino-South Tyrol and Andreas Wagner, Vienna, Austria, for preparing the samples. Joachim Gröbner, Clausthal, kindly provided tourmaline samples from the Erzgebirge; Lars Epple, Gerlingen, Germany, and Herbert Kaiser, Maria Enzersdorf, Austria, samples from the Erongo Region. Franz Brandstätter, Naturhistorisches Museum, Wien, is thanked for semiquantitative analyses, Jan Cempírek, now Moravské Zemské Muzeum, Brno, Czech Republic, for a sample from Nedvědice, and Conrad Linde, Jena, Germany, for the sample from Nejdek. We sincerely thank John M. Hughes and Peter Bačík for constructive comments on this manuscript. This work was supported in part by Austrian Science Fund (FWF) project no. P23012-N19 and no. P26903-N19 to AE, by NASA grant NNG04GG12G to MDD and NSF grant EAR-0337816 to GRR.

\section{References}

Bloodaxe, E. S., Hughes, J. M., Dyar, M. D., Grew, E. S., Guidotti, C. V. (1999): Linking structure and chemistry in the schorl-dravite series. Am. Mineral., 84, 922-928.

Bosi, F. \& Lucchesi, S. (2004): Crystal chemistry of the schorldravite series. Eur. J. Mineral., 16, 335-344.

—, - (2007): Crystal chemical relationships in the tourmaline group: Structural constraints on chemical variability. Am. Mineral., 92, 1050-1063.

Boudreaux, A., Simmons, W., Falster, A., Webber, K. (2014): Tourmaline geochemistry of the Erongo Granite, Namibia. $21^{\text {st }}$ General Meeting of the IMA (IMA2014), Gauteng, South Africa, September 1-5; Abstract Vol., p. 255.

Bruker AXS Inc. (2001): SaintPlus, version 6.45. Bruker AXS Inc., Madison, Wisconsin, USA.

Burianek, D. \& Novák, M. (2004): Morphological and compositional evolution of tourmaline from nodular granite at Lavičky near Velké Mezičirirí, Moldanubicum, Czech Republic. J. Czech Geol. Soc., 49, 81-90.

Clark, C.M., Hawthorne, F.C., Ottolini, L. (2011): Fluor-dravite, $\mathrm{NaMg}_{3} \mathrm{Al}_{6} \mathrm{Si}_{6} \mathrm{O}_{18}\left(\mathrm{BO}_{3}\right)_{3}(\mathrm{OH})_{3} \mathrm{~F}$, a new mineral of the tourmaline group from the Crabtree emerald mine, Mitchell County, North Carolina: description and crystal structure. Can. Mineral., 48, 57-62.
Del Moro, A. \& Visonà, D. (1982): The epiplutonic Hercynian complex of Bressanone (Brixen, Eastern Alps, Italy). Petrologic and radiometric data. N. Jb. Mineral. Abh., 145, 66-85.

Dixon, A., Cempírek, J., Groat, L.A. (2014): Mineralogy and geochemistry of pegmatites on Mount Begbie, British Columbia. Can. Mineral., 52, 129-164.

Dyar, M.D., Taylor, M.E., Lutz, T.M., Francis, C.A., Guidotti, C.V., Wise, M. (1998): Inclusive chemical characterization of tourmaline: Mössbauer study of Fe valence and site occupancy. Am. Mineral., 83, 848-864.

Ertl, A. (2006): Über die Etymologie und die Typlokalitäten des Minerals Schörl [About the etymology and the type localities of schorl]. Mitt. Österr. Mineral. Ges., 152, 7-16.

Ertl, A., Hughes, J.M., Marler, B. (2001): Empirical formulae for the calculation of $\langle T-\mathrm{O}\rangle$ and $X-\mathrm{O} 2$ bond lengths in tourmaline and relations to tetrahedrally-coordinated boron. N. Jb. Mineral. Mh., 2001, 548-557.

Ertl, A., Kolitsch, U., Prowatke, S., Dyar, M.D., Henry, D.J. (2006): The F-analogue of schorl from Grasstein, Trentino - South Tyrol, Italy: crystal structure and chemistry. Eur. J. Mineral., 18, 583-588.

Ertl, A., Kolitsch, U., Meyer, H.-P., Ludwig, T., Lengauer, C.L., Nasdala, L., Tillmanns, E. (2009): Substitution mechanism in tourmalines of the "fluor-elbaite"-rossmanite series from Wolkenburg, Saxony, Germany. N. Jb. Mineral. Abh., 186, 51-61.

Ertl, A., Rossman, G.R., Hughes, J.M., London, D., Wang, Y., O'Leary, J.A., Dyar, M.D., Prowatke, S., Ludwig, T., Tillmanns, E. (2010): Tourmaline of the elbaite-schorl series from the Himalaya Mine, Mesa Grande, California, U.S.A.: A detailed investigation. Am. Mineral., 95, 24-40.

Ertl, A., Kolitsch, U., Dyar, M.D., Meyer, H.-P., Henry, D.J., Rossman, G.R., Prem, M., Ludwig, T., Nasdala, L., Lengauer, C.L., Tillmanns, E. (2011): Fluor-schorl, IMA 2010-067. CNMNC Newsletter No. 8, April 2011. Mineral. Mag., 75, 289-294.

Ertl, A., Kolitsch, U., Dyar, M.D., Hughes, J.M., Rossman, G.R., Pieczka, A., Henry, D.J., Pezzotta, F., Prowatke, S., Lengauer, C.L., Körner, W., Brandstätter, F., Francis, C.A., Prem, M., Tillmanns, E. (2012): Limitations of $\mathrm{Fe}^{2+}$ and $\mathrm{Mn}^{2+}$ site occupancy in tourmaline: evidence from $\mathrm{Fe}^{2+}$ - and $\mathrm{Mn}^{2+}$-rich tourmaline. Am. Mineral., 97, 1402-1416.

Faye, G.H., Manning, P.G., Nickel, E.H. (1968): The polarized optical absorption spectra of tourmaline, cordierite, chloritoid and vivianite: Ferrous-ferric electronic interaction as a source of pleochroism. Am. Mineral., 53, 1174-1201.

Fischer, R.X. \& Tillmanns, E. (1988): The equivalent isotropic displacement factor. Acta Crystallogr., C44, 775-776.

Fischer, R.X., Lengauer, C., Tillmanns, E., Ensink, R.J., Reiss, C.A., Fantner, E.J. (1993): PC-Rietveld Plus, a comprehensive Rietveld analysis package for PC. Mat. Sci. Forum., 133-136, 287-292.

Förster, H.-J., Tischendorf, G., Trumbull, R.B., Gottesmann, B. (1999): Late-collisional granites in the Variscan Erzgebirge, Germany. J. Petrol., 40, 1613-1645.

Fortier, S. \& Donnay, G. (1975): Schorl refinement showing composition dependence of the tourmaline structure. Can. Mineral., 13, 173-177.

Gasharova, B., Mihailova, B., Konstantinov, L. (1997): Raman spectra of various types of tourmaline. Eur. J. Mineral., 9, 935-940. 
Hawthorne, F.C. (1996): Structural mechanisms for light-element variations in tourmaline. Can. Mineral., 34, 123-132.

- (2002): Bond-valence constraints on the chemical composition of tourmaline. Can. Mineral., 40, 789-797.

Henry, D.J. (2005): Fluorine - X-site vacancy avoidance in natural tourmaline: internal vs. external control. 2005 Goldschmidt Conference, May 20-25, Moscow, Idaho, USA, Abstracts Vol., abstr. no. 1318.

Henry, D.J. \& Dutrow, B. (1996): Metamorphic tourmaline and its petrologic applications. in "Boron: Mineralogy, Petrology and Geochemistry", E.S. Grew \& L.M. Anovitz, eds. Rev. Mineral., 33, 503-557.

—, - (2011): The incorporation of fluorine in tourmaline: internal crystallographic controls or external environmental influences? Can. Mineral., 49, 41-56.

Henry, D.J., Novák, M., Hawthorne, F.C., Ertl, A., Dutrow, B.L., Uher, P., Pezzotta, F. (2010): Nomenclature of the tourmalinesupergroup minerals. Am. Mineral., 96, 895-913.

Kolitsch, U., Husdal, T. A., Brandstätter, F., Ertl, A. (2011): New crystal-chemical data for members of the tourmaline group from Norway: occurrences of fluor-schorl and luinaite-(OH). Norsk Bergverksmuseum Skrift, 46, 17-24.

Kolitsch, U., Andresen, P., Husdal, T. A., Ertl, A., Haugen, A., Ellingsen, H. V., Larsen, A. O. (2013): Tourmaline-group minerals from Norway, part II: Occurrences of luinaite- $(\mathrm{OH})$ in Tvedalen, Larvik and Porsgrunn, and fluor-liddicoatite, fluorelbaite and fluor-schorl at Ågskardet, Nordland. Norsk Bergverksmuseet Skrift, 50, 23-41.

Kreuzeder, A. (1949): Der Pegmatit von Grasstein. Universitätsverlag, Wagner, Innsbruck.

MacDonald, D.J. \& Hawthorne, F.C. (1995): The crystal chemistry of $\mathrm{Si} \Leftrightarrow \mathrm{Al}$ substitution in tourmaline. Can. Mineral., 33, 849-858.

Mathesij, J. (1562): Sarepta oder Bergpostill sampt der Jochimßthalischen kurtzen Chroniken. Johann vom Berg \& Ulrich Newber, Nürnberg, 333 p. (in German).

Mattson, S.M \& Rossman, G.R. (1987): $\mathrm{Fe}^{2+}-\mathrm{Fe}^{3+}$ interactions in tourmaline. Phys. Chem. Minerals, 14, 163-171.

Müller, A., Thomas, R., Wiedenbeck, M., Seltmann, R., Breiter, K. (2006): Water content of granitic melts from Cornwall and Erzgebirge: a Raman spectroscopy study of melt inclusions. Eur. J. Mineral., 18, 429-440.

Niedermayr, G. \& Schnaitmann, E.A. (2010): Neuigkeiten aus Namibia. Mineralien-Welt, 21(6), 89-96.

Niedermayr, G., Brandstätter, F., Schnaitmann, E.A., Walter, F. (2012): Neuigkeiten aus Namibia. Mineralien-Welt, 23(4), $80-86$.

Nonius. (2007): COLLECT; DENZO-SMN. Nonius BV, Delft, The Netherlands.

Novák, M., Selway, J. B., Houzar, S. (1998): Potassium-bearing, fluorine-rich tourmaline from metamorphosed fluorite layer in leucocratic orthogneiss at Nedvědice, Svratka Unit, western Moravia. J. Czech Geol. Soc., 43, 37-44.

Novák, M., Henry, D., Hawthorne, F.C., Ertl, A., Uher, P., Dutrow, B., Pezzotta, F. (2009): Nomenclature of the tourmaline-group minerals. Report of the Subcommittee on Tourmaline Nomenclature to the International Mineralogical Association's Commission on New Minerals, Nomenclature and Classification, $45 \mathrm{p}$.
Otwinowski, Z., Borek, D., Majewski, W., Minor, W. (2003): Multiparametric scaling of diffraction intensities. Acta Crystallogr., A59, 228-234.

POWCALIB Version Beta 0.977. (1990): Program for calibrating powder data. Institut für Mineralogie und Kristallographie, University of Vienna, Vienna, Austria.

Ralph, J. (2015a): Mindat.org - the mineral database: Dravite. Mindat, Surrey, England. http://www.mindat.org/min1318.html (accessed May 25 2015).

- (2015b): Mindat.org - the mineral database: Schorl. Mindat, Surrey, England. http://www.mindat.org/min-3578.html (accessed May 25 2015).

Romer, R.L., Thomas, R., Stein, H.J., Rhede, D. (2007): Dating multiply overprinted Sn-mineralized granites - examples from the Erzgebirge, Germany. Mineral. Deposita, 42, 337-359.

Rottura, A., DelMoro, A., Caggianelli, A., Bargossi, G.M., Gasparotto, G. (1997): Petrogenesis of the Monte Croce granitoids in the context of Permian magmatism in the Southern Alps, Italy. Eur. J. Mineral., 9, 1293-1310.

Ruschel, K., Nasdala, L., Kronz, A., Hanchar, J.M., Többens, D.M., Škoda, R., Finger, F., Möller, A. (2012): A Raman spectroscopic study on the structural disorder of monazite-(Ce). Mineral. Petrol., 105, 41-55.

Schiffner, A. (1839): Handbuch der Geographie, Statistik und Topographie des Königreiches Sachsen. Erste Lieferung, den Zwickauer Kreisdirectionsbezirk enthaltend. Leipzig, Friedrich Fleischer, 532 p.

Sheldrick, G.M. (2008): A short history of SHELX. Acta Crystallogr., A64, 112-122.

Shirose, Y. \& Uehara, S. (2013): Li tourmaline from Nagatare, Fukuoka Prefecture, Japan. J. Mineral. Petrol. Sci., 108, 238-243.

Taran, M.N. \& Rossman, G.R. (2001): Optical spectra of $\mathrm{Co}^{2+}$ in three synthetic silicate minerals. Am. Mineral., 86, 889-895.

Thomas, S.-M., Thomas, R., Davidson, P., Reichart, P., KochMüller, M., Dollinger, G. (2008): Application of Raman spectroscopy to quantify trace water concentrations in glasses and garnets. Am. Mineral., 93, 1550-1557.

Trumbull, R.B., Krienitz, M.-S., Gottesmann, B., Wiedenbeck, M. (2008): Chemical and boron-isotope variations in tourmalines from an S-type granite and its source rocks: the Erongo granite and tourmalinites in the Damara Belt, Namibia. Contrib. Mineral. Petrol., 155, 1-18.

Tschiedel, J. (2000a): Die Geschichte des Zschorlauer Wolframitbergbaues (Teil 2). Amtsblatt der Gemeinde Zschorlau, 22, 8-9.

- (2000b): Die Geschichte des Zschorlauer Wolframitbergbaues (Teil 4). Amtsblatt der Gemeinde Zschorlau, 24, 10-12.

- (2006): Der Zschorlauer Wolframit-Bergbau. in "Der Berg ist frei. Bergbau im Erzgebirge", S. Woidtke, H. Meinel, J. Tschiedel, Ch. Lang, eds. Bd. 4, 1. Auflage. Verlag Siegfried Woidtke, Aue, Germany. 225-258.

Wivel, C. \& Mørup, S. (1981): Improved computational procedure for evaluation of overlapping hyperfine parameter distributions in Mössbauer spectra. J. Phys. E: Scientific Instr., 14, 605-610.

Received 31 May 2015

Modified version received 12 August 2015

Accepted 18 August 2015 